\title{
Nck2 promotes human melanoma cell proliferation, migration and invasion in vitro and primary melanoma-derived tumor growth in vivo
}

Mélissa Labelle-Côté ${ }^{1,3}$, Julie Dusseault ${ }^{3}$, Salma Ismaill ${ }^{3}$ Aude Picard-Cloutier ${ }^{3}$, Peter M Siegel ${ }^{2}$ and Louise Larose ${ }^{3^{*}}$

\begin{abstract}
Background: Nck1 and Nck2 adaptor proteins are involved in signaling pathways mediating proliferation, cytoskeleton organization and integrated stress response. Overexpression of Nck1 in fibroblasts has been shown to be oncogenic. Through the years this concept has been challenged and the consensus is now that overexpression of either Nck cooperates with strong oncogenes to transform cells. Therefore, variations in Nck expression levels in transformed cells could endorse cancer progression.
\end{abstract}

Methods: Expression of Nck1 and Nck2 proteins in various cancer cell lines at different stages of progression were analyzed by western blots. We created human primary melanoma cell lines overexpressing GFP-Nck2 and investigated their ability to proliferate along with metastatic characteristics such as migration and invasion. By western blot analysis, we compared levels of proteins phosphorylated on tyrosine as well as cadherins and integrins in human melanoma cells overexpressing or not Nck2. Finally, in mice we assessed tumor growth rate of human melanoma cells expressing increasing levels of Nck2.

Results: We found that expression of Nck2 is consistently increased in various metastatic cancer cell lines compared with primary counterparts. Particularly, we observed significant higher levels of Nck2 protein and mRNA, as opposed to no change in Nck1, in human metastatic melanoma cell lines compared with non-metastatic melanoma and normal melanocytes. We demonstrated the involvement of Nck2 in proliferation, migration and invasion in human melanoma cells. Moreover, we discovered that Nck2 overexpression in human primary melanoma cells correlates with higher levels of proteins phosphorylated on tyrosine residues, assembly of Nck2dependent pY-proteins-containing molecular complexes and downregulation of cadherins and integrins. Importantly, we uncovered that injection of Nck2-overexpressing human primary melanoma cells into mice increases melanoma-derived tumor growth rate.

Conclusions: Collectively, our data indicate that Nck2 effectively influences human melanoma phenotype progression. At the molecular level, we propose that Nck2 in human primary melanoma promotes the formation of molecular complexes regulating proliferation and actin cytoskeleton dynamics by modulating kinases or phosphatases activities that results in increased levels of proteins phosphorylated on tyrosine residues. This study provides new insights regarding cancer progression that could impact on the therapeutic strategies targeting cancer.

\footnotetext{
* Correspondence: louise.larose@mcgill.ca

${ }^{3}$ Polypeptide Laboratory, Division of Endocrinology, Department of Medicine and Research Institute of the McGill University Health Centre, McGill

University, Montreal, Quebec, Canada

Full list of author information is available at the end of the article
}

\section{Ciomed Central}

(c) 2011 Labelle-Côté et al; licensee BioMed Central Ltd. This is an Open Access article distributed under the terms of the Creative Commons Attribution License (http://creativecommons.org/licenses/by/2.0), which permits unrestricted use, distribution, and reproduction in any medium, provided the original work is properly cited. 


\section{Background}

Melanoma skin cancer is one of the most devastating types of cancer, extremely aggressive with high metastatic potential. Melanoma metastasis to distant organs is the primary cause of human cancer-related deaths. Worldwide, the incidence of cutaneous malignant melanoma is increasing faster than any other type of cancer. Cutaneous melanoma originates from pigment-producing melanocytes localized at the epidermal-dermal junction in human skin and develops through different steps [1]. Among various hypotheses, it is proposed that these involve radial (RGP) and vertical (VGP) aberrant growth phases of preexisting nevi or at new site. Then to metastasize at distant sites, melanoma detach from a primary lesion, acquire motility and proteolytic activities to reach lymphatic and blood circulation and undergo growth to distinct organs, all this according to stepwise molecular changes involving defined genetic events $[2,3]$. However, the exact mechanisms underlying this devastating process are complex and somehow still poorly understood. From a molecular point of view, oncogenic activation of the mitogen-activated protein kinase (MAPK) pathway, due to somatic mutations in B-RAF (V600E), is frequently observed in melanoma (70\%) [4].

In mammals, the family of Nck (non-catalytic region of tyrosine kinase) proteins is represented by two highly conserved members, Nck1 and Nck2, composed of three $\mathrm{N}$-terminal SH3 (Src homology 3) domains followed by a unique C-terminal SH2 (Src homology 2) domain and devoid of any catalytic activity [5,6]. Like other SH2/ SH3 domain-containing proteins, Nck1 and Nck2 behave as adaptor proteins by physically coupling activated membrane receptors to specific downstream effectors [7]. In mice, individual Nck knockout resulted in no phenotype, confirming redundancy of Nck proteins, while early embryonic lethality of the double Nck knockout mice revealed their crucial role in embryonic development [8]. However, regardless that Nck1 and Nck2 share high amino acid identity, and common cellular functions and binding partners, increasing evidence support specific roles and proteins interactions, as well as tissue expression patterns for these adaptors [7,9-15]. Previous studies have reported that overexpression of Nck1 in fibroblasts induces cellular transformation and that these cells form tumors in mice $[16,17]$. Furthermore, either Nck has been shown to cooperate with potent oncogenes ( $\mathrm{v}$-Abl and Ras) to transform cells, influence cell morphology and anchorage-independent growth [6]. Although, these studies strongly suggest a role for Nck in cancer development, the mechanism by which Nck oncogenic potential is achieved still remains to be established.
Originally the Nck1 cDNA was isolated from a human melanoma cDNA expression library using a monoclonal antibody produced against the human melanoma-associated antigen [5], which has no similarity with Nck1. This suggests that the Nck1 mRNA might be abundant in human melanoma. Most recently, the Nck2 gene was found as being overexpressed in human metastatic melanoma compared with non-metastatic melanoma lesions [18]. In agreement, the cancer microarray database Oncomine (https://www.oncomine.org/) reports Nck2 as a gene upregulated in several human cancer cell lines, including human melanoma. Therefore, the concept that deregulated expression of Nck adaptor proteins could contribute to promote melanoma development and/or progression deserves further investigation. In the present study, using human melanoma cell lines harboring the activating B-RAF (V600E) mutation, that are well defined for stage of cancer progression $[19,20]$, we demonstrate that Nck2 protein and mRNA levels are increased in human metastatic melanoma cells compared with human primary melanoma cells that rarely metastasis. We show that Nck2 promotes cell proliferation, migration and invasion in human melanoma cells. In addition, using an in vivo xenograft model, we provide evidence that increased Nck2 expression in human primary melanoma cells promotes melanoma-derived tumor growth rate. Collectively, our findings indicate that Nck2 plays a role in human melanoma progression.

\section{Methods \\ Cell lines}

The Wistar melanoma cell lines (WM278, WM1232, WM115, 1205Lu, WM164, WM1617 and 451Lu) were obtained from Dr Meenhard Herlyn (PA, USA). Human Epidermal Melanocytes (HEM) cell line was purchased from Cell Applications Inc. Murine colon carcinoma cell (CT26, CT36 and CT51) were obtained from Dr. Nicole Beauchemin (McGill University, Montreal, QC). Breast cancer cell lines (MCF10, MCF7, T47D, MDA-MB-231) were kindly provided by Dr. Morag Park (McGill University, Montreal, Qc).

\section{Cell culture}

Unless specified, all chemicals used in this study are from regular commercial sources. Cells were maintained at $37^{\circ} \mathrm{C}$ in $5 \% \mathrm{CO}_{2}-95 \% \mathrm{O}_{2}$ atmosphere. HEK293, colon and breast cancer cell lines were grown in DMEM (Dulbecco's modified Eagle's medium) containing 10\% FBS and supplemented with $100 \mathrm{Units} / \mathrm{ml}$ of penicillin, 100 $\mu \mathrm{g} / \mathrm{ml}$ of streptomycin and $0.25 \mu \mathrm{g} / \mathrm{ml}$ of Amphotericin B. Melanoma cell lines were grown in RPMI 1640 supplemented with $2 \mathrm{mg} / \mathrm{ml} \mathrm{NaHCO}_{3}$ and $0.3 \mathrm{mg} / \mathrm{ml}$ glutamine. MCF10 cells were grown in DMEM containing 
$5 \%$ Horse Serum (Invitrogen), $20 \mu \mathrm{g} / \mathrm{ml}$ of mouse epidermal growth factor (mEGF, Collaborative Biomedical Products), $10 \mu \mathrm{g} / \mathrm{ml}$ of insulin and $0.1 \mu \mathrm{g} / \mathrm{ml}$ of cholera toxin. To induce MCF10 cell differentiation, cells were grown in media in absence of mEGF but supplemented with $0.5 \mu \mathrm{g} / \mathrm{ml}$ of hydrocortisone for two days. HEM (human epidermal melanocyte) cells were grown in HEM media (Cell Applications Inc.) and cultured according to the manufacturer's instructions.

To analyze phospho-tyrosine proteins, cells were exposed to protein phosphotyrosine phosphatase inhibitor (pervanadate $\left(\mathrm{Na}_{3} \mathrm{VO}_{4}\right)$ or bpVPhen, $100 \mu \mathrm{M}, 15$ min at $37^{\circ} \mathrm{C}$ ) prior to be harvested and total cell lysates processed for anti-phosphotyrosine western blot as reported below. Alternatively, total cell lysates (2 mg protein) were incubated with indicated antibodies $(4 \mu \mathrm{g})$ for 2 hours at $4{ }^{\circ} \mathrm{C}$ and $40 \mu \mathrm{l}$ of $50 \%$ slurry solution of Protein-A immobilized on Sepharose beads (Santa Cruz Biotech.) were added for an additional 2 hours of incubation at $4^{\circ} \mathrm{C}$. Immunoprecipitated samples were washed $3 \mathrm{X}$ with lysis buffer before to be finally recovered in Laemmli buffer and processed for anti-phosphotyrosine western blot as reposted below.

\section{Antibodies}

Nck polyclonal antibodies were raised by immunizing rabbits with GST-Nck fusion proteins as antigens. Crude serum samples were Protein-A-purified (ProChem, MA) and further tested for Nck specificity as described below. A pan-Nck antibody (1793), which recognizes both Nck isoforms was raised against residues 1-251 containing the three SH3 domains of human Nck1 as previously reported [21]. Nck1 antibody (2383) and Nck2 antibody (3313) were raised against isoform specific amino acid sequence in between the last $\mathrm{SH} 3$ and the SH2 domain of each Nck as reported earlier [15]. Other antibodies used are: CrkII (C-18), Integrin $\beta 3$ (H-96), phospho-tyrosine (clone PY99), HA (Y-11) and GFP (B-2) from Santa Cruz Biotech. Antibodies against Integrin $\beta 1$ (anti-CD29, clone 18), E-Cadherin (clone 34) and N-Cadherin (clone 32) were purchased from BD (ON, Canada). Antibodies to detect vinculin (clone h-VIN-1) and Tubulin (TUB2.1) were from Sigma-Aldrich, USA. Secondary antibodies coupled to HRP were from Bio-Rad Inc. Rhodamine-coupled to mouse anti-IgG was bought at Jackson ImmunoResearch Inc. Phalloidin-coupled to AlexaFluor ${ }^{\circledR} 555$ and 488 were purchased from Molecular Probes (Invitrogen, CA, USA)

\section{Cell lysis and western blots}

Cell lysates were prepared in lysis buffer $(50 \mathrm{mM}$ HEPES pH 7.4, 150 mM NaCl, 10\% Glycerol, 1\% Triton $\mathrm{X}-100,1.5 \mathrm{mM} \mathrm{MgCl}_{2}, 1 \mathrm{mM}$ EGTA, $10 \mathrm{mM}$ Sodium
Pyrophosphate, $100 \mathrm{mM}$ Sodium Fluoride, supplemented with the protease inhibitors Aprotinin and Leupeptin at $1 \mu \mathrm{g} / \mathrm{ml}$ and PMSF at $1 \mathrm{mM}$. Lysates normalized for protein content (Bradford protein assay, Bio-Rad) were prepared in Laemmli buffer, heated, subjected to SDS-PAGE on $10 \%$ acrylamide gels and transferred onto nitrocellulose membranes. For western blot analyses, membranes were blocked in TBS (Tris-buffered saline) containing $10 \%$ dry milk and $0.1 \%$ Tween-20, and then incubated overnight at $4{ }^{\circ} \mathrm{C}$ with indicated primary antibodies appropriately diluted in the blocking solution. For pY western blot, blocking and primary antibody solution was TBS containing $5 \%$ bovine serum albumin (BSA, Sigma) and 0.1\% Tween-20. Next morning, the membranes were washed twice with TBS for 5 minutes followed by two 5 minutes washes using TBS-T (TBS$0.1 \%$ Tween-20) and two 5 minutes washes with TBS. The membranes were then incubated with secondary antibody appropriately diluted in milk-blocking solution for 1 hour and washed as above. Finally, signal was detected using ECL Plus Western Blotting Detection System (GE Healthcare, UK) and XR film exposure.

\section{RNA isolation and RT-PCR}

Total RNA was isolated from melanoma cells using the TRIZOL (Invitrogen) according to the manufacturer's protocol. Briefly, cells from $100-\mathrm{mm}$ dishes $\left(1 \times 10^{6}\right.$ cells) were suspended in $7.8 \mathrm{ml}$ of TRIZOL. The aqueous and organic phases were separated after addition of chloroform. Precipitated RNA by isopropyl alcohol addition was washed in $70 \%$ ethanol and dissolved in RNase-free water. RNA concentration and purity $\left(\mathrm{OD}_{260 / 280}\right)$ was measured using an Ultrospec 2100 Pro UV/visible Spectrophotometer (Fisher Scientific, ON). First-strand cDNA synthesis was generated by reverse transcriptase reaction in a final volume of $50 \mu \mathrm{l}$. For this, $2.0 \mu \mathrm{g}$ of total RNA were mixed in a total reaction volume of $20 \mu \mathrm{l}$ of RNAse free water containing $1 \mu \mathrm{M}$ Oligo $\mathrm{d}(\mathrm{T})_{20}$ for Nck amplifications or $6 \mu \mathrm{g}$ of Random Primers for $18 \mathrm{~S}$ amplification. The reactions were incubated at $65^{\circ} \mathrm{C}$ for $5 \mathrm{~min}$ and quenched on ice. Then, the $\mathrm{RT}$ reaction was assembled by adding $10 \mu \mathrm{l}$ of the $5 \mathrm{X}$ $1^{\text {st }}$ strand buffer (Invitrogen), $5 \mu$ of $0.1 \mathrm{M}$ DTT (Invitrogen), $2.5 \mu \mathrm{l}$ of RNase Inhibitor $(40 \mathrm{U} / \mu \mathrm{l})$ (Invitrogen), $2.5 \mu \mathrm{l}$ of $10 \mathrm{mM}$ dNTPs, $5 \mu \mathrm{l}$ of $50 \mathrm{mM} \mathrm{MgSO}_{4}$ and 2.5 $\mu \mathrm{l}$ of Superscript III $(200 \mathrm{U} / \mu \mathrm{l})$ (Invitrogen). Samples were incubated at $37^{\circ} \mathrm{C}$ for $50 \mathrm{~min}$ and deactivated at $70^{\circ} \mathrm{C}$ for $15 \mathrm{~min}$. PCR amplification was performed using $0.5 \mu \mathrm{l}$ of cDNA template in a final volume of 50 $\mu \mathrm{l}$ containing $5 \mu \mathrm{l}$ of 10X PCR Enhancer buffer (Invitrogen), $1.5 \mathrm{mM} \mathrm{MgCl}_{2}, 0.2 \mathrm{mM}$ dNTPs, $50 \mathrm{pM}$ of specific forward and reverse primers, $10 \mu \mathrm{l}$ of Amplification buffer (Invitrogen) and $1 \mathrm{U}$ of Taq DNA polymerase (Invitrogen) and DEPC water. Primers used were: Nck1 
forward 5'-GCCAGATTCTGCATCTCCTG-3', Nck1 reverse 5'-ACACTTGCCCAGTATTTAGG-3', Nck2 forward 5'-CGAGTACCCCGCCAATGG-3' and Nck2 reverse 5'-CCCGTCACTGAGGACCACC-3'. Reactions were carried out on PTC-100 Programmable Thermal Controller (MJ Research Inc.) according to the following program conditions: initial denaturation at $94^{\circ} \mathrm{C}$ for 1 min, followed by $1 \mathrm{~min}$ at $94^{\circ} \mathrm{C}, 30$ seconds of annealing $\left(47^{\circ} \mathrm{C}\right.$ for Nck $1,53^{\circ} \mathrm{C}$ for Nck 2 and $55^{\circ} \mathrm{C}$ for $\left.18 \mathrm{~S}\right)$ and $1 \mathrm{~min}$ at $72^{\circ} \mathrm{C}$. The final elongation step was 10 minutes at $72^{\circ} \mathrm{C}$ and the samples were kept at $4^{\circ} \mathrm{C}$ until analysis. PCR products were separated on a $1 \%$ agarose gels and imaged using an NIH Image J 1.30 system. Fifteen, 20, 25 and 30 cycles of PCR amplification products were analyzed to confirm that the amplification was in the linear range for each gene. Ratios of Nck1 and Nck2 over $18 \mathrm{~S}$ were calculated from similar assays performed in triplicate and repeated three times.

\section{Cell transfection}

Human HA-tagged Nck2 cDNA generously provided by Dr. Wei Li (University of Southern California, LA, CA) was subcloned into the retroviral vector pLXSN (Clonetech Laboratories Inc., CA, USA) and the viral particles produced using the GP2-293 cell line according to the manufacturers' instructions. Human Nck2 cDNA was also subcloned into the pEGFP-C1 plasmid (BD, NJ, USA). To establish stable clones of human WM278 primary melanoma overexpressing GFP or GFP-Nck2, cells plated in $100-\mathrm{mm}$ dishes $\left(1 \times 10^{6}\right.$ cells) were transiently transfected with $10 \mu \mathrm{g}$ of plasmid DNA (pEGFP or pEGFP-Nck2) using calcium phosphate and following selection with neomycin, clones were isolated, amplified and analyzed for GFP or GFP-Nck2 by western blot. 451Lu cells plated at 40-60\% confluence were transfected with either 100 nM Nck2 or control siRNA 13379 (Ambion, Austin, TX) using Lipofectamine Plus reagent according to the manufacturer's protocol and analyzed for protein expression after 24 or $48 \mathrm{~h}$.

\section{Proliferation assays}

Briefly, cells $\left(4 \times 10^{3}\right)$ were seeded in 96-well plates and $24,48,72$ or $96 \mathrm{~h}$ after, cells were fixed by adding glutaraldehyde (20 min, final concentration $1 \%$ ). Then, fixed cells were washed twice with deionised water and stained with Crystal Violet (20 $\mathrm{min}, 0.4 \%$ in $10 \%$ ethanol, Sigma). The excess of Crystal Violet was removed by washing the cells three times with water and finally, incorporated Crystal Violet was dissolved in 10\% acetic acid and read at $570 \mathrm{~nm}$ using a spectrophotometer (Beckman Coulter). Wells without cells, but containing medium were used as blank value that was subtracted from all values. Data were expresses a raw OD at 570 $\mathrm{nm}$ or as ratio of OD at specific time point over initial OD at day 1.

\section{Wound healing assays}

Cell migration was assessed in classical wound healing assays. Confluent monolayer cells in a 6-well plate were wounded using a plastic pipette tip (P200) and rinsed with PBS before to add back culture medium. The bottoms of the wells were marked to indicate where the initial pictures of the wound area were taken. After $8 \mathrm{~h}$ incubation at $37^{\circ} \mathrm{C}$, pictures $(10 \mathrm{X})$ of the same areas were recorded using an Axiovert $200 \mathrm{M}$ microscope

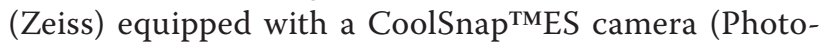
metric $^{\circledR}$, Roper Scientific) and closure of the wound evaluated using Metamorph ${ }^{\circledR}$ (V6.3, Molecular Devices Corp.).

\section{Cell invasion assays using Transwells}

Melanoma cells $\left(1 \times 10^{5}\right)$ resuspended in $10 \%$ serum containing medium were added to the top chamber of a Transwell ( $8 \mu \mathrm{m}$, DD Biosciences, NJ, USA) pre-coated with matrigel ${ }^{\mathrm{TM}}$ (BD Biosciences, NJ, USA) diluted in ice-cold PBS $(175 \mu \mathrm{g} / \mathrm{ml})$ at a total of $35 \mu \mathrm{g}$ per well and allowed to migrate for $24 \mathrm{~h}$. To evaluate the amount of cells that had invaded through each transwell, excess of media was discarded and the transwells were washed once with PBS and then placed in trypsin solution $(0.025 \%)$ to release the invaded cells underside of the transwells and in the bottom chamber. Total invaded cells were estimated using Calcein AM (BD Biosciences, NJ, USA) as recommended by the manufacturer. Data were normalized according to the respective total amount of cells for each line plated at the same time in adjacent wells devoid of transwells to take into account variations in cell number between cell lines.

\section{Spheroid formation assays}

Spheroid formation and culture in 3D were performed according to the hanging drop method [22]. Briefly, $2 \times$ $10^{4}$ cells in $20 \mu \mathrm{l}$ of culture medium were suspended on the lid of tissue culture dishes containing $10 \mathrm{ml}$ of culture medium for $48 \mathrm{~h}$ to form spheroids. Then spheroids were transferred in culture dishes containing culture medium and on 2\% agar (Agar Select, Invitrogen, CA, USA) at the bottom. After $72 \mathrm{~h}$ of growth in suspension, individual spheroid has been transferred in 4-well plate containing $80 \%$ collagen type IV (PureCol ${ }^{\circledR}$, Advanced BioMatrix) in RPMI without FBS. Following $30 \mathrm{~min}$ at $37^{\circ} \mathrm{C}$ to allow collagen polymerization, $500 \mu \mathrm{l}$ of RPMI containing 10\% FBS was added to each well. Images were recorded initially and at 12-24 hr intervals as reported above for wound healing assays. Spheroid invasion was determined qualitatively as either positive or negative comparing sequential images. 


\section{Actin and focal adhesions}

Cells were plated at $3 \times 10^{4}$ cells/well on glass coverslips pre-coated or not with various extracellular matrices and incubated in culture medium for $24 \mathrm{~h}$. All steps were carried at room temperature and coverslips were rinsed with PBS between each step. Cells were fixed in freshly prepared $3.7 \%$ formaldehyde for $10 \mathrm{~min}$, permeabilized in $0.2 \%$ Triton-X-100 for 5 min and blocked in $0.1 \%$ BSA for $30 \mathrm{~min}$. For vinculin staining, cells were incubated with primary monoclonal anti-vinculin antibody (1:400) for $1 \mathrm{~h}$ and with a mixture of secondary tetramethylrhodamine isothiocyanate-conjugated phalloidin-conjugated goat mouse antibody (TRITC-GAM, Sigma) for $30 \mathrm{~min}$. Actin staining was performed by incubating the coverslips for $30 \mathrm{~min}$ with PhalloidinAlexaFluor ${ }^{\circledR} 555$. Coverslips were mounted by inverting them on glass slides using Prolong anti-fade mounting media (Molecular Probes). Coverslips were examined on a Zeiss Axiovert $200 \mathrm{M}$ microscope (Zeiss) using 40X or oil immersion $63 \times$ objective lens. Fluorescent images were captured using a CoolSnap ${ }^{\mathrm{TM}} \mathrm{ES}$ camera (Photometric $^{\circledR}$, Roper Scientific) and analyzed using Meta$\operatorname{morph}^{\circledR}$ (V6.3, Molecular Devices Corp.).

\section{Tumor growth in vivo}

WM278 primary melanoma cells either parental, overexpressing GFP (C2) or GFP-Nck2 at low (N7) or high (N14) levels were grown in RPMI medium supplemented with $10 \%$ FBS to $80 \%$ confluency. Cells $\left(5 \times 10^{6}\right)$ resuspended in $500 \mu \mathrm{l}$ at $50 \%$ Matrigel $^{\mathrm{TM}}$ were injected subcutaneously in the right flank of 6-week-old CD-1 Nude mice (Charles River, Qc, Canada) ( $\mathrm{n}=5$ for each group). Tumors development was followed for 20 weeks. Tumor size was measured every week with calipers to

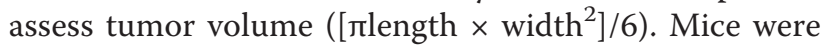
housed in McGill University Animal facilities at the Genome building. Mice experiments were conducted under a McGill University-approved animal use protocol (Dr. P.M. Siegel) in accordance with guidelines established by the Canadian Council on Animal Care.

\section{Data analysis and statistics}

Densitometry analysis results are expressed as means \pm S.E.M. Student's $t$ test was used to evaluate the statistical significance of the results. A p $\leq$ value 0.05 is assumed to be significant.

\section{Results}

Nck2 protein and mRNA levels are increased in human metastatic melanoma cell lines

To investigate the potential involvement of Nck proteins in human melanoma development and progression, we first analyzed total Nck protein levels in human melanoma cell lines at different stages of cancer progression and compared with normal human melanocytes. The human melanoma cell lines used in this study were provided by the laboratory of Dr. Meenhard Herlyn at the Wistar Institute (PA, USA) and already used in vivo for tumorigenicity and experimental metastasis [23,24]. Mainly, these include the WM278, a melanoma cell line derived from a human primary tumor in vertical growth phase that rarely metastasis; WM1617, a WM278 sister melanoma cell line derived from lymph nodes metastasis in the same patient few years later; $451 \mathrm{Lu}$, a melanoma cell line isolated from lung metastasis in mice injected with the WM164 cell line, which is a human melanoma cell line isolated from lymph nodes metastasis similar to WM1617, but from a different patient.

From western blots performed using a rabbit polyclonal antibody that equally recognizes both Nck isotypes (Pan-Nck, Additional file 1) [21], we observed higher levels of Nck proteins in highly metastatic melanoma (WM164, 451Lu, 1205Lu and WM1232) compared with weakly metastatic primary melanoma (WM115 and WM278) and normal melanocyte (FW2294) cell lines (Figure 1A). Further analyses using in-house generated Nck isoforms specific antibodies (Additional file 1) [15] revealed that increased expression of Nck in metastatic melanoma cells is mainly due to drastic higher expression levels of Nck2 (Figure 1B, compare WM164 and 451Lu with WM278). Additional comparison of highly metastatic (WM1617) and weakly metastatic (WM278) human melanoma cell lines isolated from the same patient (Figure 1B), further confirmed increased expression of Nck2 in human metastatic melanoma. Interestingly, Nck1 protein levels normalized according to actin or tubulin loading control were comparable among the human melanoma cell lines investigated (Figure 1B and Additional file 2). In addition, we also found no change in expression levels of other $\mathrm{SH} 2 / \mathrm{SH} 3$ domain-containing signaling proteins, such as PLC- $\gamma 1, \mathrm{p} 85$ of PI3K, Grb2 and Crk, as normalized for actin or tubulin loading control (Additional file 2 and data not shown). Altogether, these results suggest a specific role for Nck2 in human melanoma progression.

To assess whether increased expression of Nck2 protein levels in human metastatic melanoma cells correlates with upregulated transcription of Nck2 gene, we compared Nck1 and Nck2 mRNA levels in three human melanoma cell lines at different stages of progression and in human primary melanocytes (HEM) by performing RT-PCR using Nck isoforms specific primers. In the linear range of PCR amplification, no significant change in Nck1 mRNA levels was detected in all human melanoma cell lines and compared with HEM (Figure 2A). In contrast, we observed a strong increase in Nck2 mRNA levels in all human melanoma cell lines compared with HEM. In addition, compared with primary 


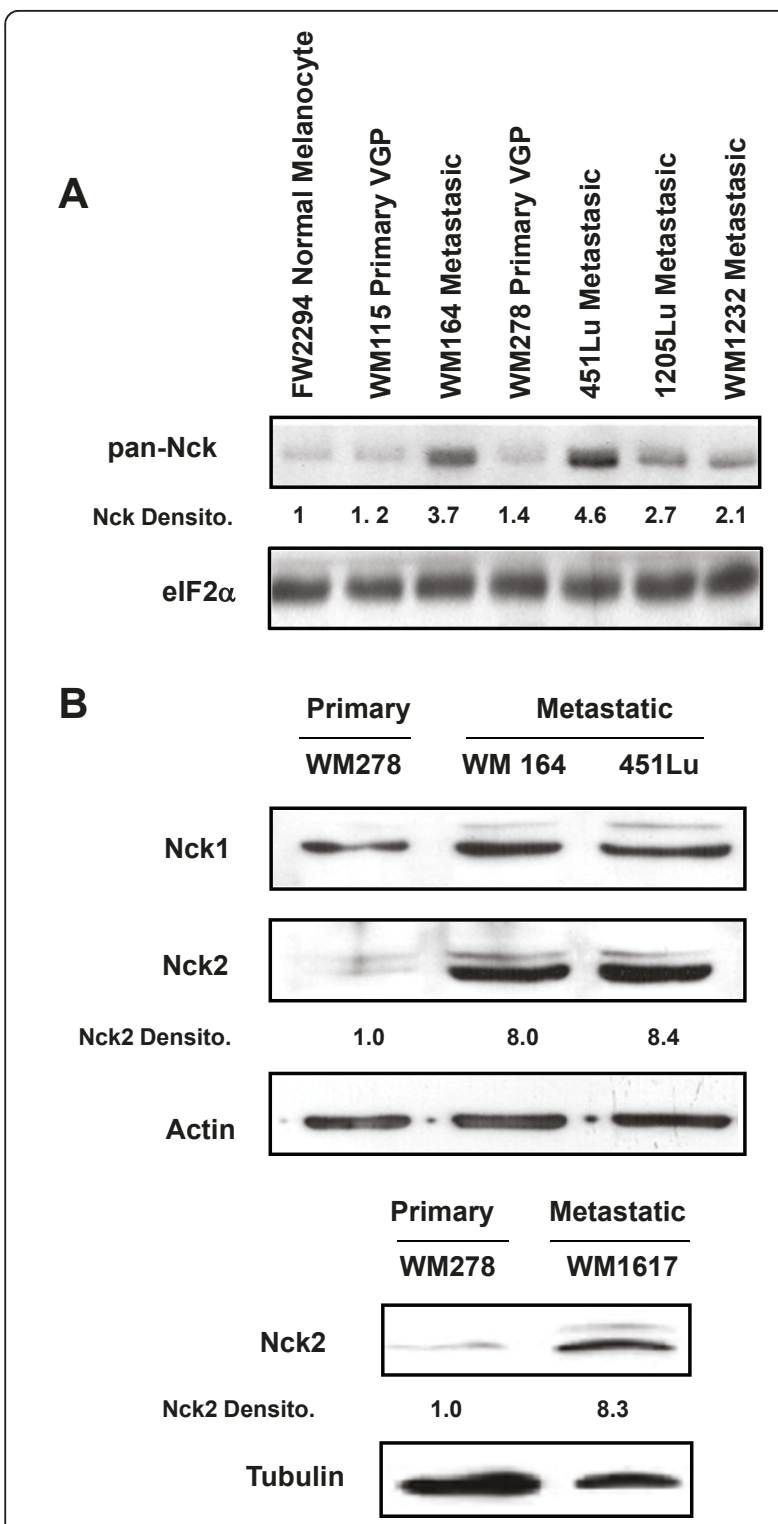

Figure 1 Nck expression in human melanoma cell lines at different stages of cancer progression. Equivalent amount of total proteins from human primary and metastatic melanoma cell lysates $(30 \mu \mathrm{g})$ were subjected to western blot analysis using indicated antibodies. (A) Pan-Nck antibodies recognize Nck1 and Nck2. elF2 $\alpha$ was used as loading control. (B) Nck1 and Nck2 are specific Nck isotypes antibodies (Additional file 1) and $\beta$-actin or tubulin was detected as loading controls. Quantification of Nck1 and Nck2 signals, evaluated in the linear range of detection by densitometry, are reported below the blots. Human Melanoma Cell Lines Characteristics: FW2294: normal melanocyte; WM115: poorly metastatic primary melanoma in vertical growth phase and with round morphology; WM164: elongated metastatic melanoma isolated from lymph nodes; WM278: poorly metastatic primary melanoma in vertical growth phase and with mixed morphology; WM1617: elongated metastatic melanoma derived from lymph nodes, sister match of WM278; 451Lu: elongated metastatic melanoma selected in lungs of mice injected with WM164 cells; 1205Lu: round metastatic melanoma selected in mice; WM1232: round metastatic melanoma. melanoma cells (WM278), metastatic melanoma cell lines (WM164 and 451LU) showed significant increased Nck2 mRNA levels (Figure 2B). Altogether, our results reveal that Nck2 protein and mRNA levels are significantly increased in different human metastatic melanoma cells compared with human weakly metastatic primary melanoma and melanocyte cells, suggesting Nck2 as a biological marker of human melanoma metastasis that could contribute to melanoma progression.

\section{Nck2 promotes human melanoma cell proliferation}

To demonstrate a role for Nck2 in melanoma progression, we first determined whether Nck2 regulates cell proliferation in WM278 human primary melanoma cells, which endogenously express low levels of Nck2 protein and rarely metastasis compared with its metastatic counterpart WM1617 melanoma cells. For this, we created WM278 cell lines stably overexpressing increasing levels of GFP-Nck2 (N15 < N7 < N14) or GFP as control (C2) (Figure 3A). Using these WM278 stable cell lines, we found that overexpressing high levels of Nck2 significantly enhanced cell proliferation (Figure 3B, left panel, compare clone N14 with C2). It is interesting to note though that the effect of Nck2 on WM278 primary melanoma cells proliferation seems to parallel the levels of Nck2 overexpressed (Figure 3A and $3 \mathrm{~B}$, compared N15, N7 and N14). In agreement, the WM1617 human metastatic melanoma cells that endogenously express higher levels of Nck2 compared with human primary melanoma cells, also show higher proliferative abilities than its paired WM278 primary melanoma cells that rarely metastasis (Figure 3C). As expected, we found no change in the protein levels of Nck1 or CrkII, a SH2-SH3 domain-containing adaptor protein previously identify as an oncogene [25] and recently reported to regulate sarcoma cell proliferation [26] (Figure 3C).

To confirm a role for Nck2 in melanoma cell proliferation, we assessed whether siRNA-mediated downregulation of Nck2 in human metastatic melanoma cells affects cell proliferation. As shown in Figure 4A, Nck2 siRNA transfection of 451Lu metastatic melanoma cells resulted in decreased Nck2 protein and mRNA levels, while Nck1 protein and mRNA levels were not altered. More importantly, we found that cell proliferation was significantly decreased in Nck2 depleted metastatic melanoma cells compared with control siRNA treated cells (Figure 4B). To rule out that this effect was due to increased cell death in Nck2 depleted melanoma cells, 2 days post transfection we evaluated the percentage of cells with nuclei stained by Trypan Blue and observed no difference between metastatic melanoma cells transfected with control $(8.7 \% \pm 2.5)$ and Nck2 $(7.7 \% \pm 1.7)$ siRNA. Altogether, these results indicate that Nck2 


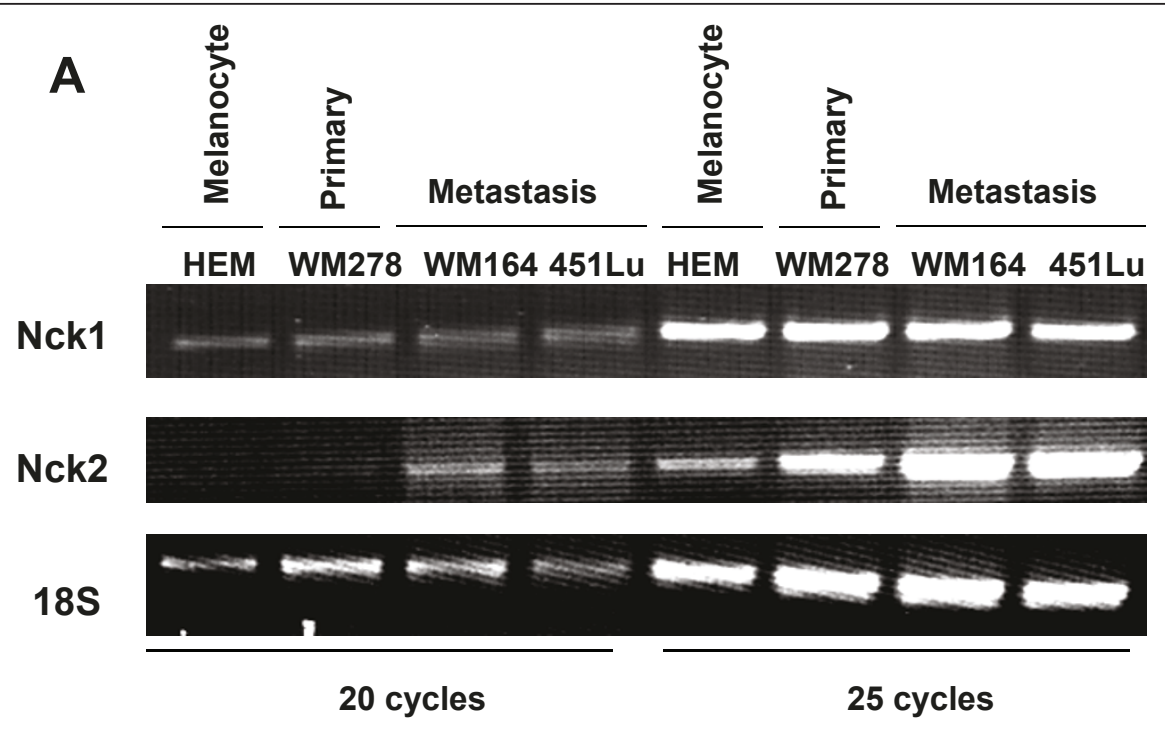

$\mathbf{B}$

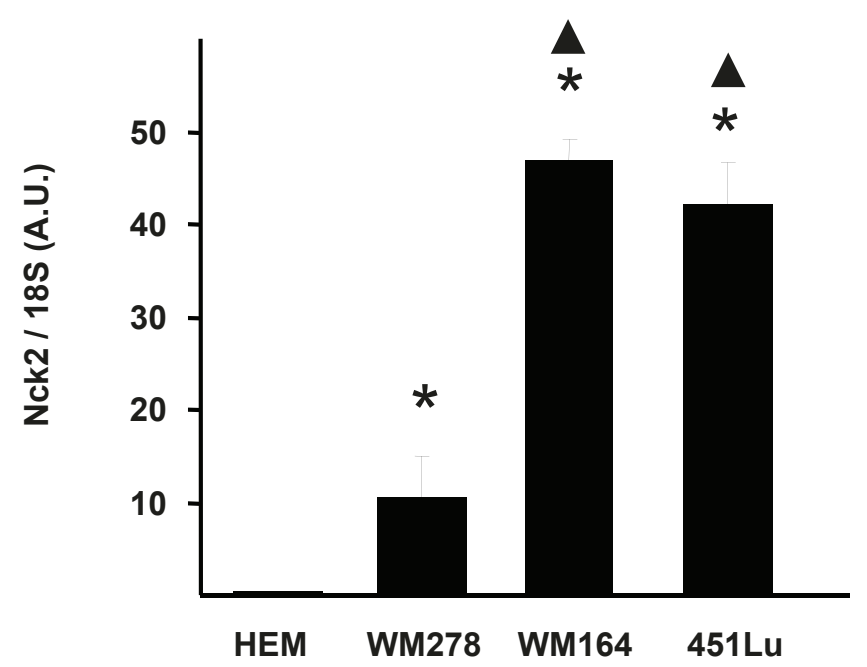

Figure 2 Nck1 and Nck2 mRNA expression in human melanocytes and melanoma cells. (A) RT-PCR amplification performed on isolated RNA from human melanocyte and melanoma cells using specific primers for human Nck1, Nck2 and 18S. Shown are PCR products after 20 and 25 cycles of amplification. HEM: human normal melanocytes; WM278: human primary melanoma that rarely metastasis; WM164: human melanoma isolated from metastasis in lymph nodes; 451Lu: lung melanoma metastasis of WM164 injected in mice. 18S is used as control. (B) Ratios of Nck1 and Nck2 mRNA over $18 \mathrm{~S}$ were calculated from quantification by densitometry of PCR amplification products in the linear range. Asterisk: $p \leq 0.001$ compared to HEM, black triangle: $p \leq 0.001$ compared to WM278.

contributes to the control of proliferation in human melanoma cells.

\section{Nck2 modulates migration and invasion of human} melanoma cells

Cancer progression involves that transformed cells must acquire motility and invasive activities. Therefore, we next determined whether Nck2 was critical to melanoma cell migration and invasion. We compared migration of WM278 primary melanoma cells overexpressing GFP
(C2) or increasing levels of GFP-Nck2 (N15 < N7 < N14) in wound healing assays. As shown in Figure 5, increasing levels of GFP-Nck2 in WM278 melanoma cells promoted migration and this was significant in cell line N14, which expresses higher levels of Nck2 proteins compared with N5 and N7 cell lines (Figure 3A). To exclude that a clonal effect is responsible of increased migration of WM278 melanoma cells overexpressing GFP-Nck2, we transiently overexpressed HA-Nck2 in WM278 primary melanoma cells using retroviral 


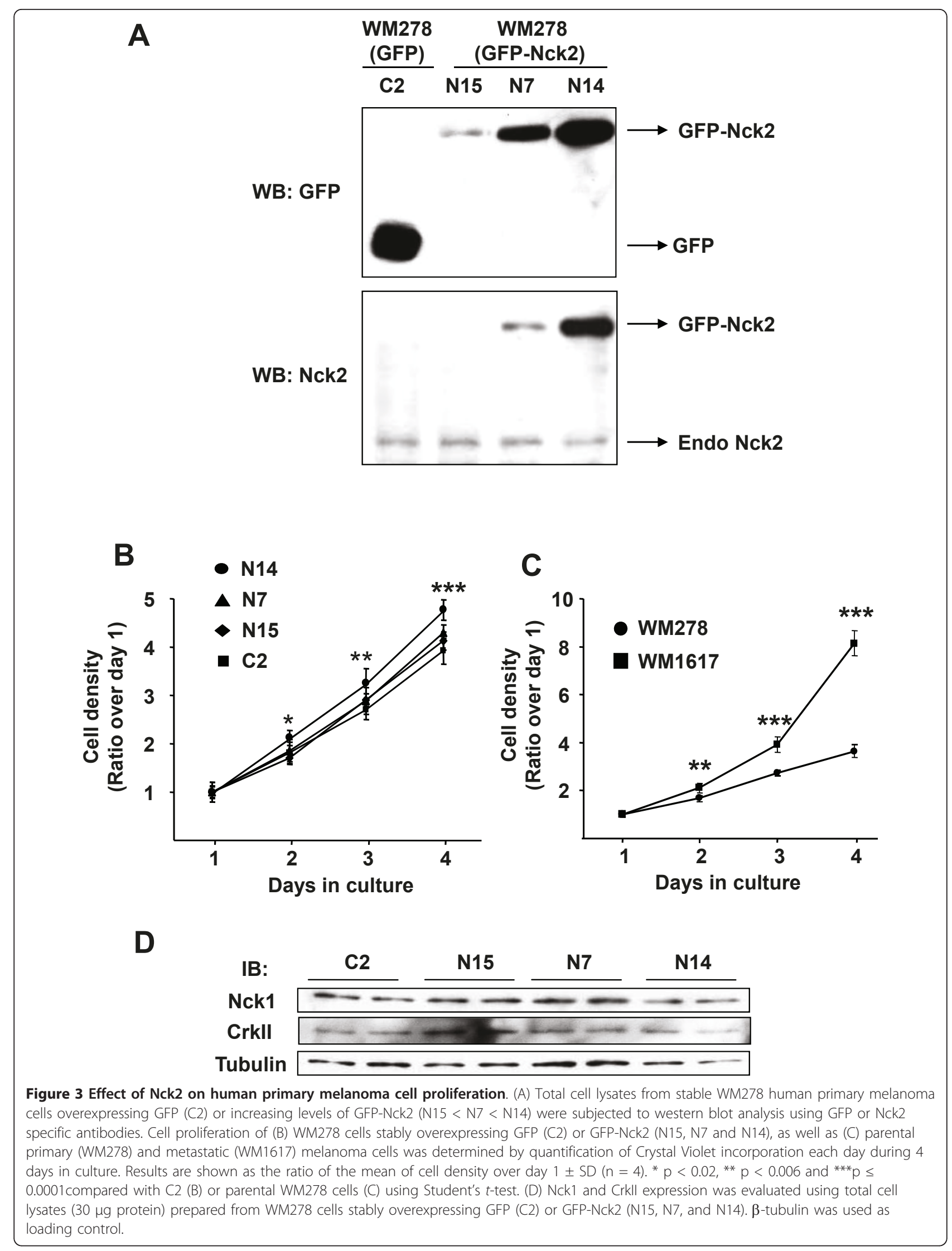




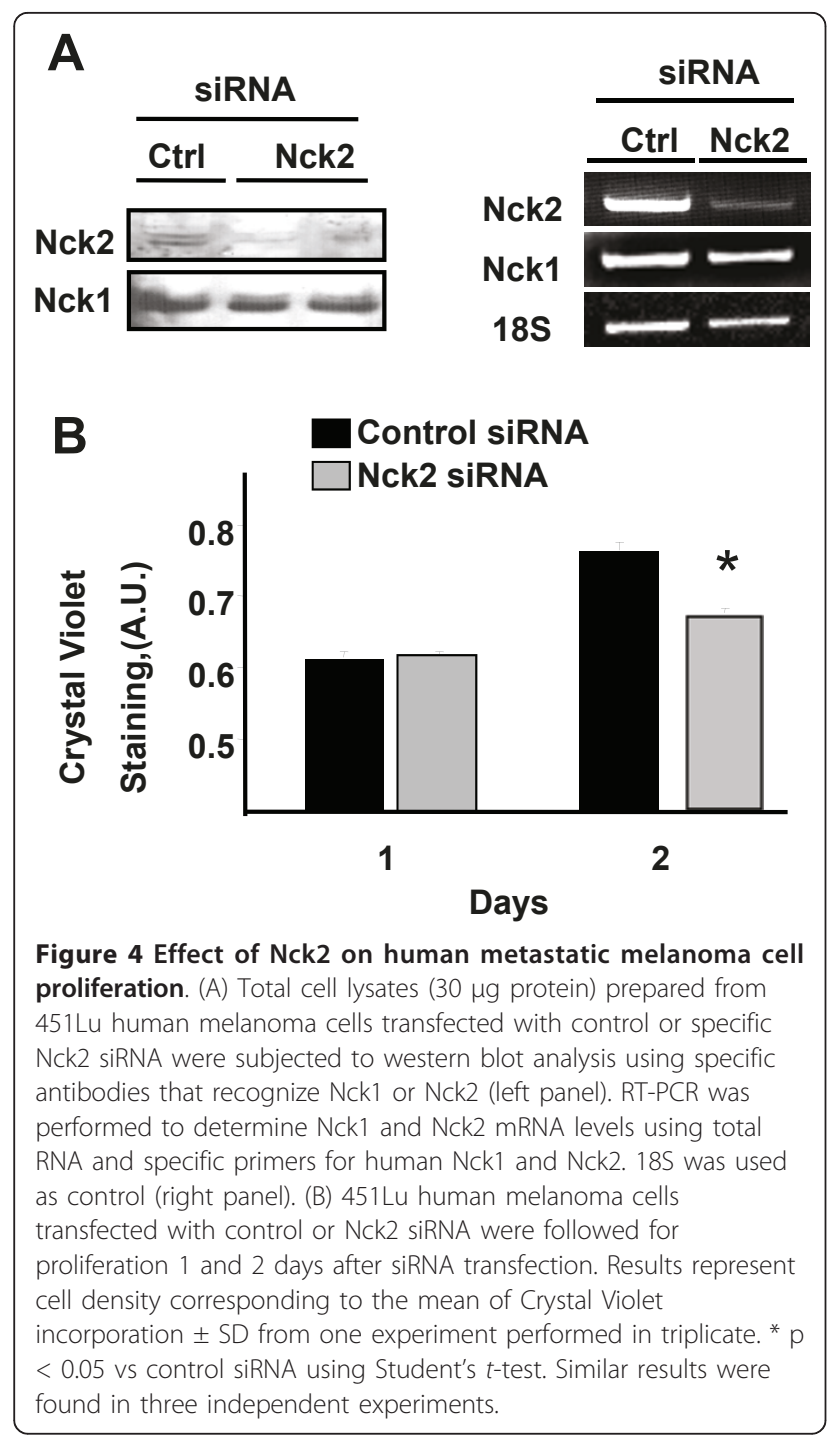

infection (Additional file 3). In this context, we still observed a significant increase in migration of WM278 human primary melanoma cells overexpressing HANck2 compared to control infected WM278 melanoma cells in wound healing assays. It is interesting to note though that the effect of Nck2 on migration was already observed 8 hours after wounding, suggesting that cell proliferation is not involved.

To determine whether overexpression of Nck2 in primary melanoma cells promotes invasion in a tumor-like context, we evaluated migration of melanoma cells at the edge of multicellular spheroids embedded into a collagen type I matrix (Figure 6A). As expected, spheroids of human primary melanoma cells overexpressing or not GFP (WM278, C2) grew as compact units devoid of cells migrating outward after $48 \mathrm{~h}$ in culture. In contrast, WM1617 human metastatic melanoma cells after $48 \mathrm{~h}$ in culture formed open-wave fragile spheroids with cells in periphery sending long projections invading the surrounding collagen. These observations are in agreement with the established invasive phenotype of WM1617 melanoma cells. Interestingly, WM278 human primary melanoma cells overexpressing GFP-Nck2 (N14) apparently did not show similar extensions from spheroid border cells, but form less compact spheroids than WM278-GFP with individual cells that detached form the mother spheroid after $48 \mathrm{~h}$ of culture into collagen gel. This observation reveals that overexpression of Nck2 in primary melanoma cells may contribute to invasiveness by promoting cell detachment and migration from primary melanoma lesion in vivo. In agreement, we found that Nck2 overexpression significantly promoted primary melanoma cells invasion through Matrigel $^{\mathrm{TM}}$ matrix in transwells assays (Figure 6B). Altogether, these results suggest that Nck2 promotes cell migration and invasion in human melanoma cells.

\section{Nck2 modulates focal adhesions in human melanoma cells}

Because Nck adaptor proteins play an important role in regulating actin cytoskeleton reorganization, we then compared actin staining in WM278 human primary melanoma cells expressing either GFP (C2) or increasing levels of GFP-Nck2 (N15 < N7 < N14) (Figure 7A). Regardless of Nck2 expression levels, we found no apparent change in actin staining in these cells. This suggests that overexpression of Nck2 has no major effect on actin polymerization and organization, as well as on overall cell morphology in human primary melanoma. In contrast, vinculin staining, which shows that GFP-Nck2 colocalizes with vinculin at focal adhesions (Figure 7B), revealed significant reduced number of focal adhesions in human primary melanoma cells overexpressing Nck2 (N14) compared with control melanoma cells (C2) (Figure 7C). Therefore, these data suggest that increased expression of Nck2 in human primary melanoma cells might facilitate melanoma migration by decreasing focal adhesions.

Nck2 promotes phosphorylation of proteins on tyrosine and downregulation of cell surface adhesion proteins in human primary melanoma cells

Protein tyrosine phosphorylation is a critical mechanism regulating focal adhesion dynamics $[27,28]$. Substantial evidence support a role for protein tyrosine kinases in focal adhesions assembly/disassembly toward the formation of invasive adhesion structures called invadopodia during cancer progression [29-33]. To investigate the mechanism by which Nck2 overexpression impinges on the phenotype of primary melanoma cells, we compared the levels of tyrosine phosphorylated proteins between human melanoma cells 


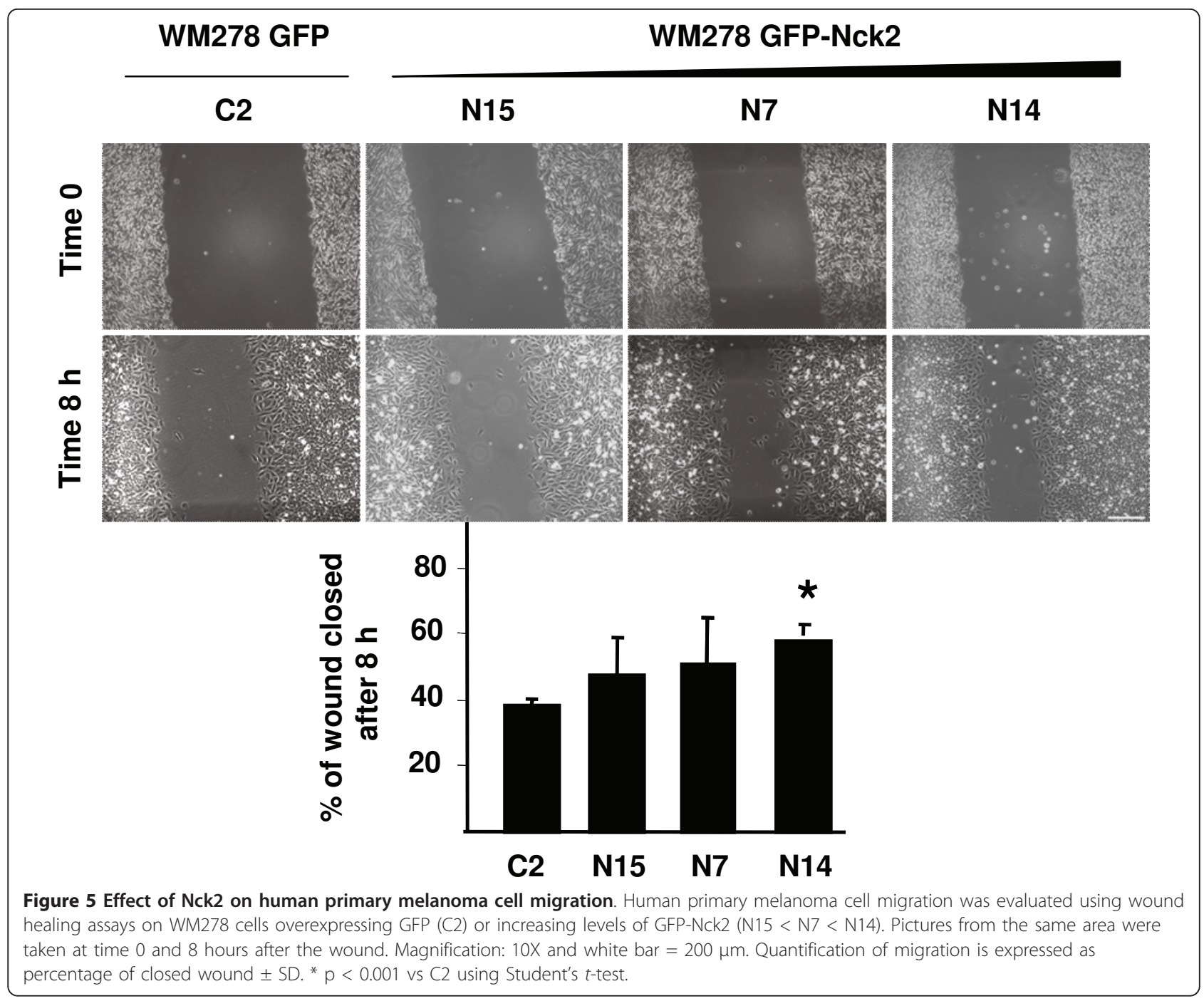

expressing different levels of Nck2 protein. To evaluate protein tyrosine phosphorylation, we exposed melanoma cells to pervanadate, a potent protein tyrosine phosphatase inhibitor [34-36] that allows tyrosine phosphorylated proteins to accumulate before harvesting the cells and performing immunoprecipitation. In these conditions, as observed in human metastatic (WM1617, WM164) compared with (WM278) melanoma cells (Figure 8A), WM278 cells overexpressing GFP-Nck2 presented increasing levels of proteins phosphorylated on tyrosine residues than WM278 control cells overexpressing GFP (Figure 8A). In addition, we found that tyrosine phosphorylated proteins coimmunoprecipitated with Nck2 (Nck2 IP) or total Nck (pan-Nck IP) were more abundant in human metastatic melanoma WM1617 cells compared with the counterpart WM278 primary melanoma cells (Figure $8 \mathrm{~B})$. We discovered also that like the metastatic WM1617 melanoma cells, the WM278 primary melanoma cells overexpressing high levels GFP-Nck2 (N14) displayed low levels of Integrin $\beta 1$ and $\beta 3$, as well as E- and N-Cadherin in Triton X-100 soluble extracts compared either with parental WM278 cells, WM278 cells overexpressing GFP (C2) or low levels of GFP-Nck2 (N7) (Figure 9). Collectively, these results reveal that increased expression of Nck2 in human primary melanoma cells promotes phosphorylation of proteins on tyrosine, concomitant with the assembly of Nck2-dependent pY-proteins containing molecular complexes and downregulation of cell surface adhesion proteins.

Nck2 promotes primary melanoma-derived tumor growth in vivo

To establish the biological relevance of our findings, we examined whether overexpression of Nck2 in human primary melanoma cells confers some tumorigenic advantage in a xenograft mouse model. To test 


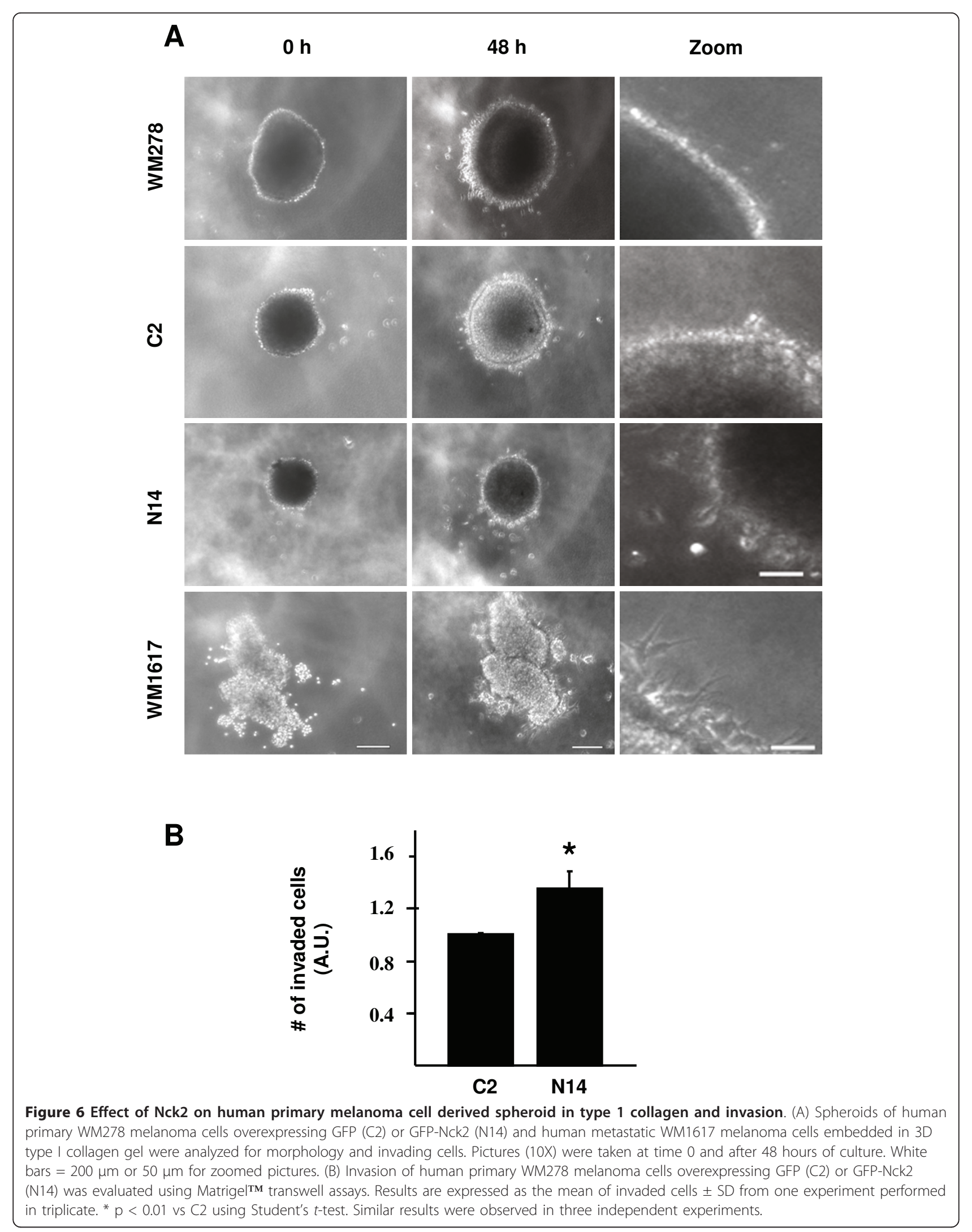



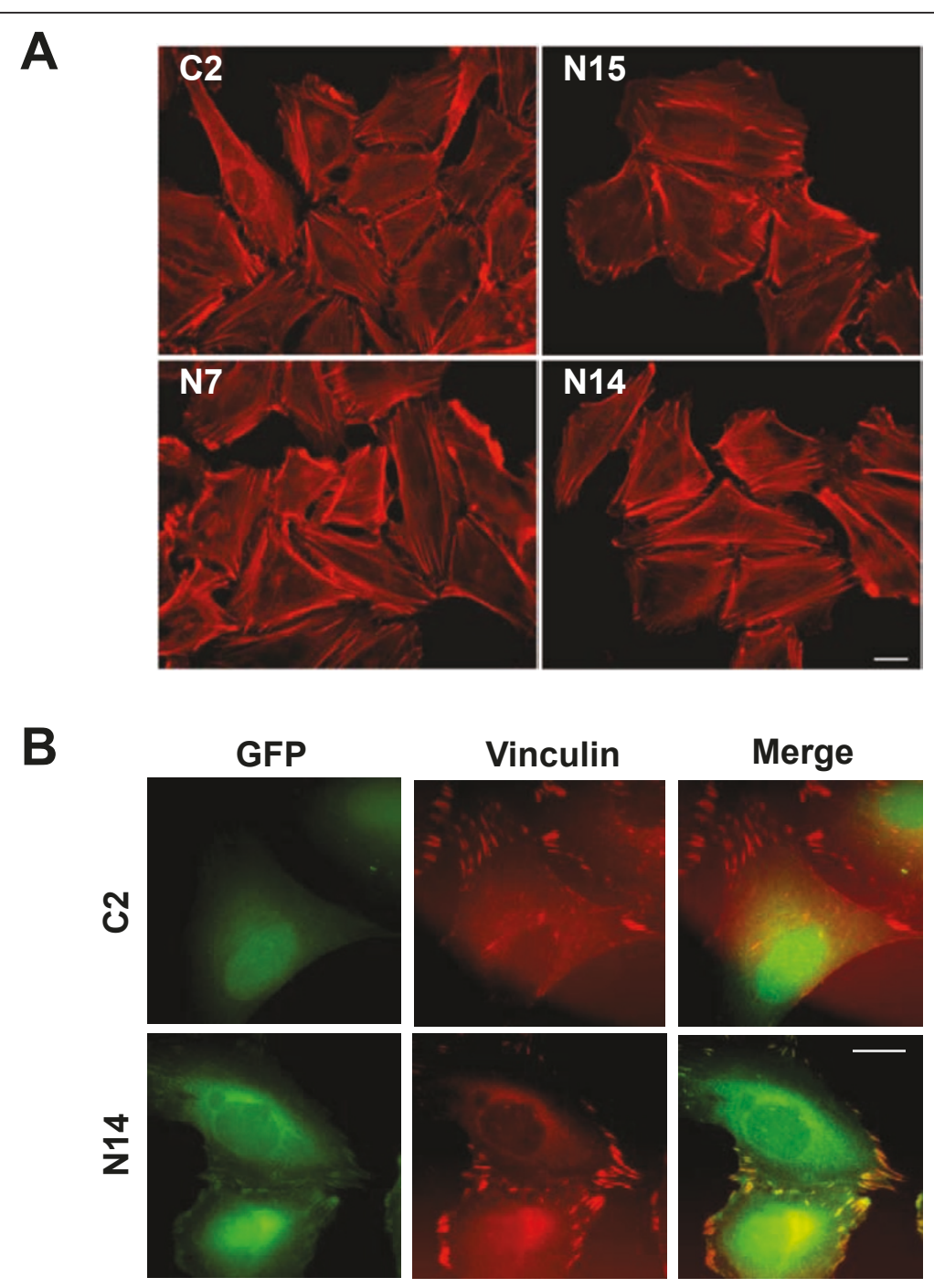

C
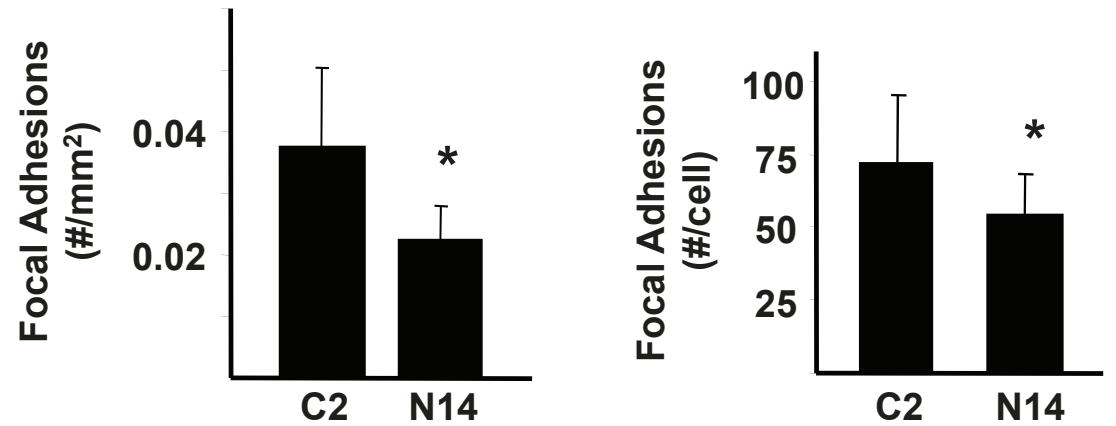

Figure 7 Effect of Nck2 on actin organization and focal adhesions in human primary melanoma cells. (A) WM278 human primary melanoma cells overexpressing GFP (C2) or increasing levels of GFP-Nck2 (N15 < N7 < N14) were submitted to actin staining using phalloidincoupled to AlexaFluor ${ }^{\mathbb{R}} 555$. Pictures were taken at 40X and white bar represent $20 \mu \mathrm{m}$. (B) Fluorescence pictures of WM278 human primary melanoma cells stably overexpressing GFP (C2) or GFP-Nck2 (N14) subjected to vinculin staining using anti-vinculin specific antibody and GAMTRICT (63X, white bar: $20 \mu \mathrm{m}$ ). (C) Manual quantification of focal adhesions as positive vinculin structures in 50 representative cell types. Results normalized for cell size are expressed as the mean of focal adhesion per $\mathrm{mm}^{2}$ or cell \pm SD. ${ }^{*} p<0.001$ vs C2 using Student's $t$-test. 


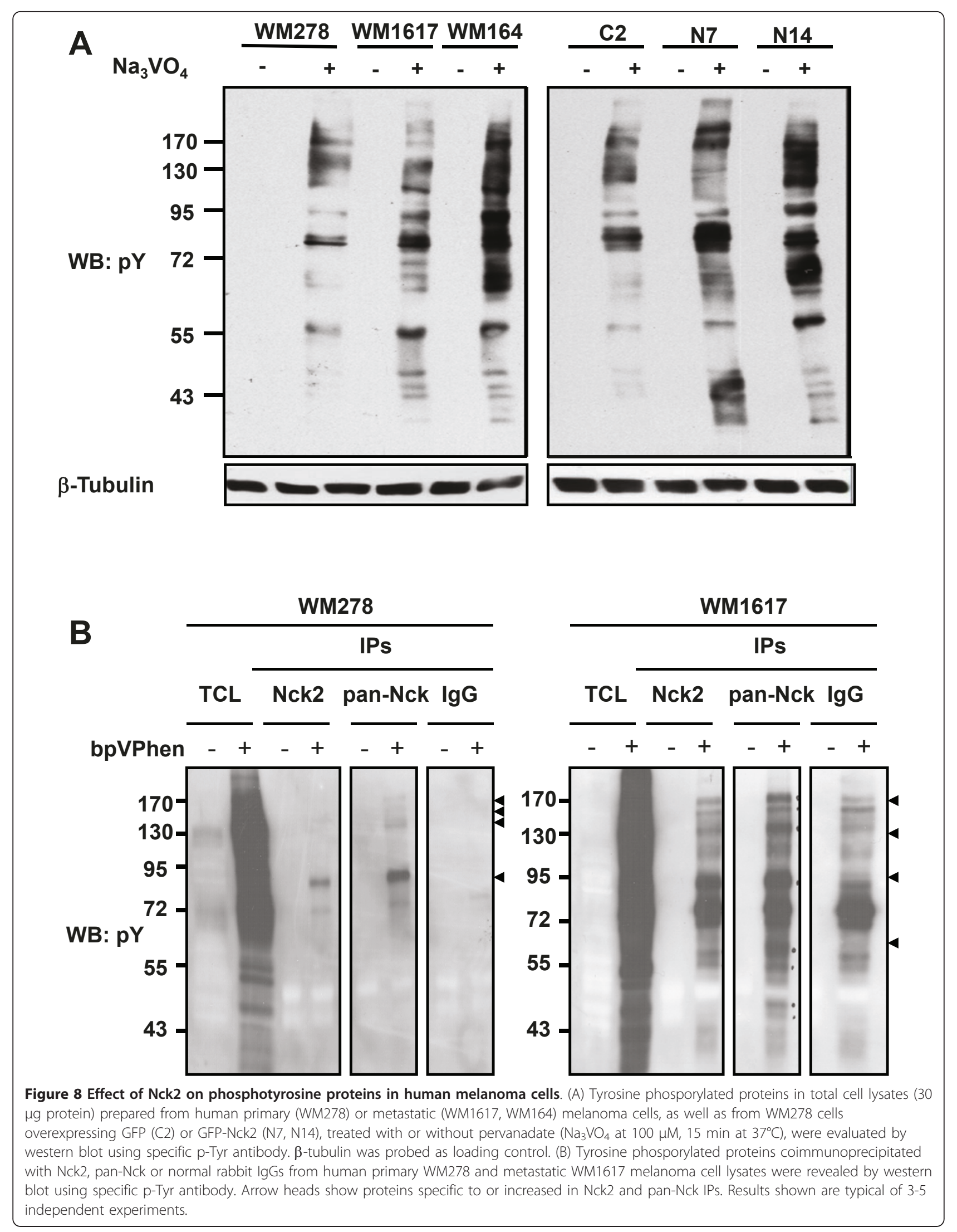




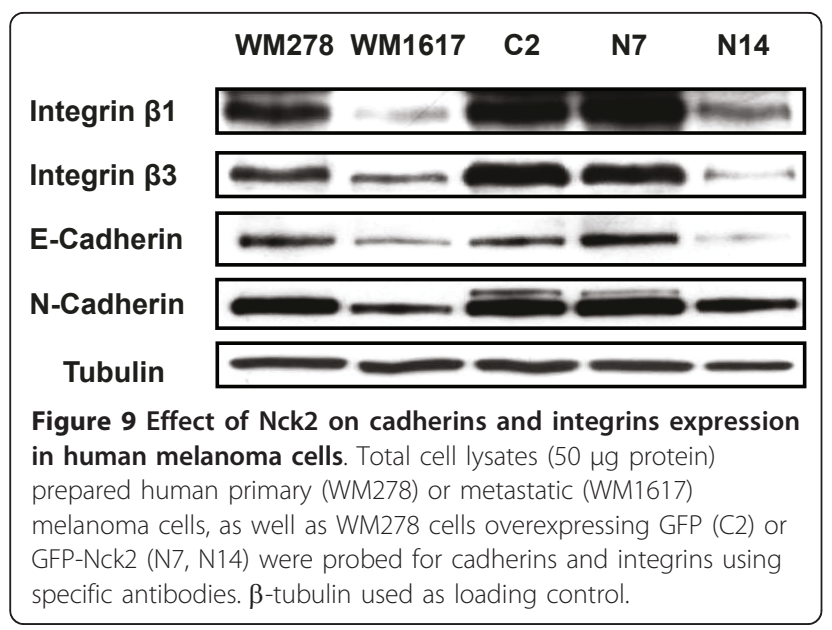

this, WM278 human primary melanoma cells overexpressing GFP-Nck2 at low (N7) or high (N14) levels, along with parental WM278 cells, WM278 cells overexpressing GFP (C2) and WM1617 human metastatic melanoma cells were injected subcutaneously into CD1 Nude mice. Two out of 5 mice injected with WM278 human primary melanoma cells overexpressing high levels of GFP-Nck2 (N14) developed tumor at the site of injection between 13-16 weeks post injection (Figure 10A). At the same time, 1 out of 5 mice that received either parental WM278 cells, WM278 melanoma cells overexpressing GFP (C2) or overexpressing low levels of GFP-Nck2 (N7) presented a subcutaneous tumor at the site of injection. In contrast, all mice injected with the metastatic WM1617 cells developed tumors at the site of injection 2-7 weeks post-injection (Figure 10A). As expected, tumors derived from metastatic WM1617 cells grew rapidly and reached maximal volume allowed between 5-11 weeks post-injection. Altogether, these observations suggest that increased expression of Nck2 in human melanoma cells is not sufficient to promote the appearance of subcutaneous tumor derived from melanoma. However, melanoma-derived tumor growth rate in mice injected with WM278 cells overexpressing GFP-Nck2 (N7 and N14) was greatly enhanced compared with tumor found in mice injected with WM278 cells parental or overexpressing GFP (C2) (Figure 10B), suggesting that increased expression level of Nck2 promotes primary melanoma-derived tumor growth rate. Subcutaneous tumors derived from WM278 cells overexpressing GFP-Nck2 (N7 and N14) could not be further monitored than few weeks after their occurrence due to the appearance of important spontaneous tumor necrosis core that required mice to be euthanized. Nevertheless, in line with our in vitro studies (Figure 3B), these results strongly support a role for Nck2 in melanoma-derived tumor growth rate in vivo.

\section{Nck2 expression is upregulated in invasive colon and breast cancer cell lines}

To find out whether increased expression of Nck2 during cancer progression is observed in other cancer types than in melanoma skin cancer, we assessed Nck isoforms protein levels in murine colon (CT) and human breast cancer cell lines at different stages of progression (Figure 11). The CT represent mouse tumorigenic colonic carcinoma cell lines established in culture from three transplantable murine tumors of colonic origin at different stages of progression [37]. Based on growth rate and metastatic spreading, CT26 is the most aggressive, while CT51 is intermediary and CT36 is the least and rarely metastasizes. Using these cells lines, we observed that Nck1 protein levels are increased in the metastatic CT26 and CT51, while just barely detected in CT36. However, when Nck1 expression levels were normalized according to actin, these variations were not statistically significant. In contrast, Nck 2 that was below detection level in CT36 and CT51, was distinctly detected in CT26, revealing increased expression of Nck2 in aggressive metastatic colon cancer cells. To determine whether expression of Nck isoforms vary during breast cancer progression, we selected few of the widely used human breast cancer cell lines (MCF-7, T47D and MDA-MB-231) and an immortalized normal human breast epithelial cell line (MCF10A). MCF-7, T47D and MDA-MB-231 are invasive ductal carcinoma of similar origin with metastatic properties [38]. Independently of estrogen receptor expression (ER+: MCF-7 and T-47D; ER-: MDA-MB-231) or epithelial/mesenchymal phenotype (epithelial-like low invasion: MCF-7 and T47D; mesenchymal-like high invasion: MDA-MB-231), Nck1 protein levels in breast cancer cells were not consistent with the cancer stage. Considering actin as loading control, Nck1 protein levels were significantly increased in T-47D cells, decreased in MDA-MB-231 cells and not change in MCF7 cells compared to MCF$10 \mathrm{~A}$ cells, excluding a potential correlation between Nck1 expression levels and breast cancer progression. In contrast, Nck2 was only detected in the most aggressive MDA-MB-231 cells, which are mesenchymal-like ER+ breast cancer cells with strong migratory and metastatic abilities [38,39]. Together these results provide the first evidence that the expression of Nck2 is increased in metastatic cancer cells of various origins and argue for a role of Nck2 in cancer progression.

\section{Discussion}

Nck1 and Nck2 SH2-SH3 domain-containing proteins have been reported to be differently expressed in 
A

\begin{tabular}{lccc}
\multicolumn{3}{c}{ A } & \multicolumn{3}{c}{ Subcutaneous tumors } \\
\hline \multirow{2}{*}{ Cell line } & No. of cells & Mice with tumors & \\
\cline { 2 - 4 } & & Weeks post-injection $^{b}$ \\
\hline WM278 & $5 \times 10^{6}$ & $1 / 5$ & 12 \\
WM278-GFP (C2) & $5 \times 10^{6}$ & $1 / 5$ & 16 \\
WM278-N7 (low Nck2) & $5 \times 10^{6}$ & $1 / 5$ & 14 \\
WM278-N14 (high Nck2) & $5 \times 10^{6}$ & $2 / 5$ & $13-16$ \\
WM1617 & $5 \times 10^{6}$ & $5 / 5$ & $2-7$ \\
\hline
\end{tabular}

B

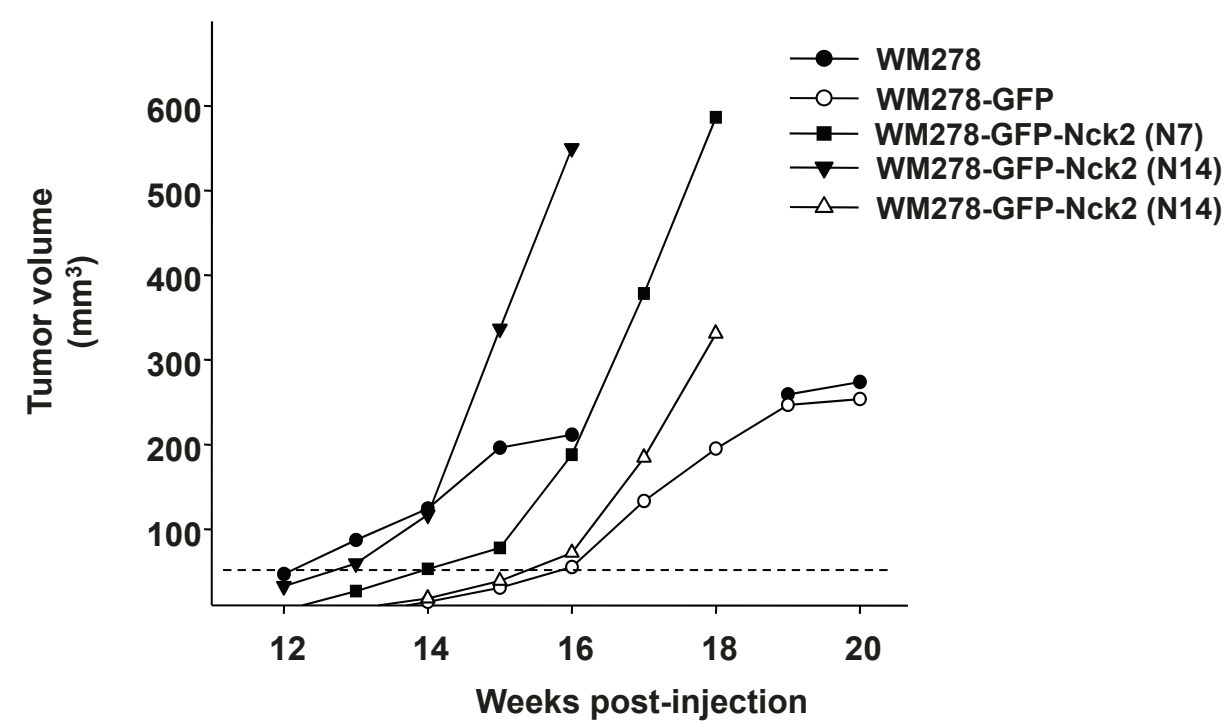

Figure 10 Effect of Nck2 on human primary melanoma-derived tumor growth in vivo. CD-1 Nude mice of 6-week-old were injected subcutaneously with human parental WM278 primary melanoma cells, WM278 cells overexpressing either GFP or GFP-Nck2, or human WM1617 metastatic melanoma cells $\left(5 \times 10^{6}\right)$ into the right flank. (A) The mice were monitored for tumor development. (B). Tumor volume progression assessed with calipers every week in indicated mice. Tumors with volume bigger than $50 \mathrm{~mm}^{3}$ (dashed line) were considered during the course of the study.

numerous mouse tissues $[8,15]$. In agreement with the ability of both Nck to collaborate with strong oncogenes to transform cells [6], Nck1 and Nck2 genes were found upregulated in several human cancer cell lines, including melanoma (https://www.oncomine.org/). However, Nck proteins expression levels in cancer tissues and possible mechanism(s) by which these adaptors contribute to cancer development have been poorly investigated to date. In this study, we provide evidence that Nck2 plays a role in promoting proliferation, migration and invasion of human melanoma cells in vitro and growth of melanoma-derived tumors in vivo, while its expression is upregulated in metastatic cancer cells, including colon, breast and melanoma.

Our investigation revealing that Nck2 overexpression in human primary melanoma cells induces metastatic characteristics point towards Nck2 sufficiency to promote metastasis phenotype. In this study, we did not address whether Nck2 is necessary for melanoma metastasis. However, we provided some insights suggesting that Nck2 could play such function. In fact, we found higher levels of Nck2 expression in metastatic compared 


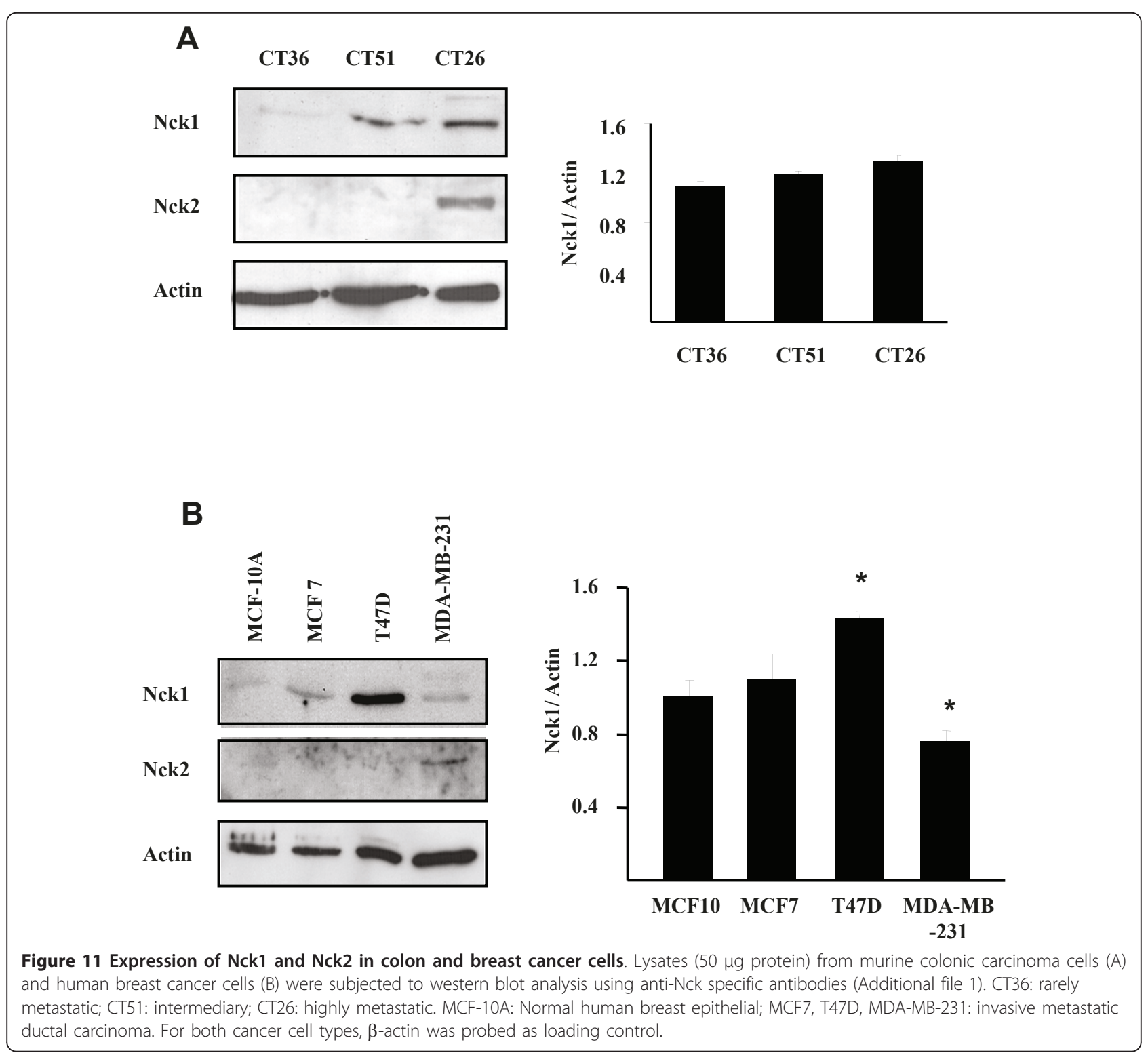

to non metastatic cell lines in three different types of cancer. In addition, we demonstrate that depletion of Nck2 in metastatic melanoma reduces cell proliferation. This does not exclude that other yet identified players could be required to fully promote metastasis in melanoma overexpressing Nck2. None the less, our findings clearly demonstrate that overexpression of Nck2 in human primary melanoma correlates with upregulation of the total phospho-tyrosine proteins content, assembly of novel Nck2-dependent pY-protein complexes and downregulation of $\mathrm{E}$ - and $\mathrm{N}$-cadherins, and $\beta-1$ and -3 integrins. E-cadherin, found at adherens junctions, is the principal effector of cell-cell adhesion [40]. Loss of Ecadherin expression in cancer cells weakens cell-cell adhesion and is associated with cancer progression, invasion and metastasis [41-43]. At the present time, there is no evidence for a direct link between E-cadherin and Nck2. Further investigation is required to elucidate the molecular events responsible for E-cadherin downregulation associated with overexpression of Nck2 in human primary melanoma cells and whether downregulation of Nck2 in metastatic human melanoma cells would restore E-cadherin expression remains to be determined. On the other hand, the degree of cancer cells cohesion in primary tumor also depends on the strength of cell-ECM contacts mediated by integrins [44]. Alteration in integrins expression has been also implicated in cancer progression, invasion and metastasis $[45,46]$. Integrins signaling associated with regulation of the actin cytoskeleton leading to adhesive attachment 
involves the activation of the focal adhesion kinase (FAK) and the integrin-like kinase (ILK) (reviewed in [47]). Interestingly, Nck2 has been shown to affect cell motility through its direct interaction with FAK [48]. Moreover, increasing evidence support a close relationship between integrins and growth factor receptor tyrosine kinases to activate signaling pathways that promote proliferation and metastatic activity (reviewed in [49]). Nck2 has been reported to function as a molecular link connecting integrins and growth factor receptor tyrosine kinases signaling pathways. In fact, Nck2 associates with numerous receptor tyrosine kinases [17,50-54] through its $\mathrm{SH} 2$ domain and using its third $\mathrm{SH} 3$ domain, it binds to a LIM domain in PINCH (Particularly Interesting Cys-His-rich Protein) [55]. PINCH, a binding protein for ILK, plays an important role in mediating integrins-induced cell-ECM interaction by directing ILK to focal adhesions [56]. It is recognized that the ILKPINCH complex participates to signaling pathways regulating fundamental cellular processes (reviewed in [57], including cell shape and migration [58]. A crucial role for Nck in regulating these processes was particularly illustrated by the findings showing that fibroblasts derived from Nck double knockout mice embryos display major defects in cell attachment, cell motility and actin remodeling [8]. Therefore, increased expression of Nck2 in human primary melanoma cells may elicit protein interactions that re-wire signaling pathways in a fashion that alters focal adhesions and promotes cell motility by interacting with FAK and PINCH. Alternatively, increased expression of Nck2 could passively destroy proper stoichiometry of molecular complexes and in this manner, indirectly contributes to cancer progression by altering signaling pathways regulating the actin cytoskeleton network supporting cell migration.

Nck proteins are known to couple activated receptor tyrosine kinases, as well as non receptor tyrosine kinases, to effectors involved in signaling pathways regulating proliferation and actin cytoskeleton dynamics [7,14,59-61]. Non-receptor protein kinases of the Src and Abl families are often overexpressed or aberrantly activated in a wide variety of human cancers and their roles in cancer progression, including proliferation, survival, motility, invasiveness, metastasis and angiogenesis, is significant. Of note, Nck directly binds to and promotes Abl activation and signaling $[62,63]$, and associates with $\mathrm{p} 60^{\mathrm{v}-}$ ${ }^{\mathrm{src}}$ in vitro [16]. c-Src has been recently reported to be overexpressed in human metastatic melanoma tumors [64]. Interestingly, Src-dependent phosphorylation of Tks5 and cortactin recruits Nck to invadopodia, where it regulates actin assembly and ECM degradation [65-67]. Invadopodia, exclusive invasive cancer cell membrane actin-based protrusions enriched in signaling and proteolytic activities, are used by invasive cancer cells to degrade the ECM and invade surrounding tissues [68-71]. It is then possible that upregulation of tyrosine phosphorylated proteins and downregulation of cadherins and integrins in human primary melanoma cells that overexpress Nck2 may endow melanoma cells with altered adhesive properties and spatial relationships that favor uncontrolled proliferation, migration and invasion.

Nck1 and Nck2 proteins are highly identical, but despite high homology, redundant functions and common binding partners, increasing evidence suggest specific roles and protein interactions [7,9-12,14], as well as specific tissue expression patterns for Nck proteins $[8,15]$. In this study, the effect of Nck1 overexpression on melanoma phenotype was not addressed. However, our results demonstrate that increased endogenous expression of Nck2 in human metastatic melanoma cells relative to primary melanoma cells and melanocytes results from increased $N c k 2$ transcription, suggesting that Nck1 and Nck2 promoters are under different regulatory controls.

\section{Conclusions}

In conclusion, in this study we provide evidence for a role of the adaptor protein Nck2 in melanoma proliferation, migration and invasion in vitro and melanomaderived tumor growth in vivo. Collectively, our data support Nck2 as a cornerstone governing the aspects that promote melanoma progression. Given other common metastatic cancer cell lines also overexpress Nck2, a general paradigm could make Nck2 a potential molecular marker of cancer progression and a novel target for anti-cancer drug therapy.

\section{Additional material}

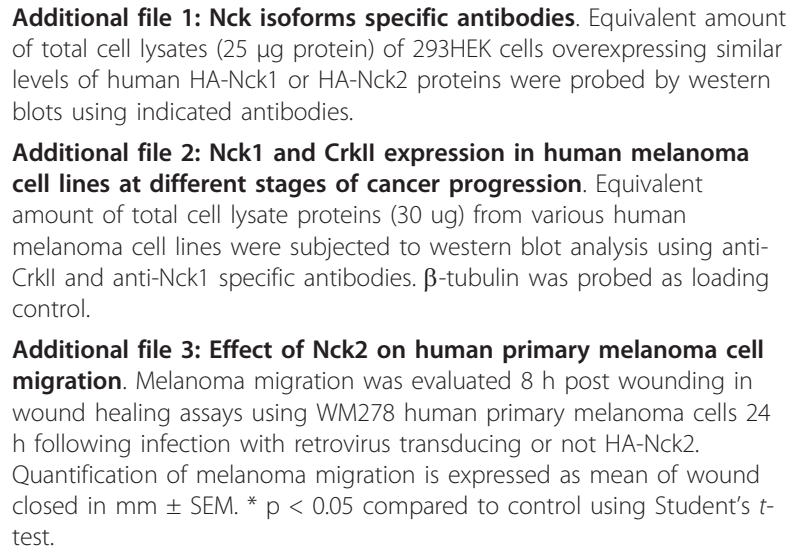

Additional file 1: Nck isoforms specific antibodies. Equivalent amount of total cell lysates $(25 \mu \mathrm{g}$ protein) of $293 \mathrm{HEK}$ cells overexpressing similar levels of human HA-Nck1 or HA-Nck2 proteins were probed by western blots using indicated antibodies.

Additional file 2: Nck1 and Crkll expression in human melanoma cell lines at different stages of cancer progression. Equivalent amount of total cell lysate proteins $(30 \mathrm{ug}$ ) from various human melanoma cell lines were subjected to western blot analysis using antiCrkll and anti-Nck1 specific antibodies. $\beta$-tubulin was probed as loading control.

Additional file 3: Effect of Nck2 on human primary melanoma cell migration. Melanoma migration was evaluated $8 \mathrm{~h}$ post wounding in wound healing assays using WM278 human primary melanoma cells 24 $\mathrm{h}$ following infection with retrovirus transducing or not HA-Nck2. Quantification of melanoma migration is expressed as mean of wound closed in $\mathrm{mm} \pm$ SEM. ${ }^{*} \mathrm{p}<0.05$ compared to control using Student's $t$ test.

\section{Acknowledgements}

This work was supported by a grant to LL from the Canadian Health Research Institutes (CIHR). MLC was supported by a studentship from the 
CIHR. JD is postdoctoral fellow supported by the Fond de la Recherche en Santé du Québec (FRSQ). SI received support from AstraZeneca. LL is FRSQ Chercheur National. We thank Caterina Russo and Dr. Josée-France Villemure for expert experimental assistance. We also thank Lama Yamani and Dr. Nathalie Lamarche-Vane for critical reading of the manuscript.

\section{Author details}

'Programmes de biologie moléculaire, Faculté de Médecine, Université de Montréal, Montréal, Québec, Canada. ${ }^{2}$ Department of Biochemistry and Goodman Cancer Research Centre, McGill University, Montreal, Quebec, Canada. ${ }^{3}$ Polypeptide Laboratory, Division of Endocrinology, Department of Medicine and Research Institute of the McGill University Health Centre, McGill University, Montreal, Quebec, Canada.

\section{Authors' contributions}

MLC participated to most experiments and contributed to the analysis of the data. JD performed experiments to generate Figure 8 and has been essential to the study design and the draft the manuscript. SI participated in the cellular and biochemical assays. APC carried out wound healing assays experiments reported in Additional file 3. PMS contributed to the conception and achievement of in vivo experiments. LL conceived the study, participated in its design and coordination, and to the preparation of the final manuscript. All authors read and approved the final manuscript.

\section{Competing interests}

The authors declare that they have no competing interests.

Received: 27 July 2011 Accepted: 12 October 2011

Published: 12 October 2011

\section{References}

1. Larue L, Beermann F: Cutaneous melanoma in genetically modified animals. Pigment cell research/sponsored by the European Society for Pigment Cell Research and the International Pigment Cell Society 2007, 20(6):485-497.

2. Gupta PB, Kuperwasser C, Brunet JP, Ramaswamy S, Kuo WL, Gray JW, Naber SP, Weinberg RA: The melanocyte differentiation program predisposes to metastasis after neoplastic transformation. Nature genetics 2005, 37(10):1047-1054.

3. Miller AJ, Mihm MC Jr: Melanoma. The New England journal of medicine 2006, 355(1):51-65

4. Pollock PM, Harper UL, Hansen KS, Yudt LM, Stark M, Robbins CM, Moses TY, Hostetter G, Wagner U, Kakareka J, et al: High frequency of BRAF mutations in nevi. Nature genetics 2003, 33(1):19-20.

5. Lehmann JM, Riethmuller G, Johnson JP: Nck, a melanoma cDNA encoding a cytoplasmic protein consisting of the src homology units SH2 and SH3. Nucleic Acids Res 1990, 18(4):1048.

6. Braverman LE, Quilliam LA: Identification of Grb4/Nck beta, a src homology 2 and 3 domain-containing adapter protein having similar binding and biological properties to Nck. J Biol Chem 1999, 274:5542-5549.

7. McCarty JH: The Nck SH2/SH3 adaptor protein: a regulator of multiple intracellular signal transduction events. BioEssays 1998, 20:913-921.

8. Bladt F, Aippersbach E, Gelkop S, Strasser GA, Nash P, Tafuri A, Gertler FB, Pawson T: The murine Nck SH2/SH3 adaptors are important for the development of mesoderm-derived embryonic structures and for regulating the cellular actin network. Molecular and cellular biology 2003, 23(13):4586-4597.

9. Buday L: Membrane-targeting of signalling molecules by $\mathrm{SH}_{2} / \mathrm{SH}_{3}$ domain-containing adaptor proteins. Biochem Biophys Acta 1999, 1422:187-204.

10. Buday L, Wunderlich L, Tamas P: The Nck family of adapter proteins. Regulators of actin cytoskeleton. Cellular signalling 2002, 14(9):723-731.

11. Cowan CA, Henkemeyer M: The SH2/SH3 adaptor Grb4 transduces Bephrin reverse signals. Nature 2001, 413(6852):174-179.

12. Lawe $\mathrm{DC}$, Hahn C, Wong AJ: The Nck SH2/SH3 adaptor protein is present in the nucleus and associates with the nuclear protein SAM68. Oncogene 1997, 14:223-231.

13. Oser M, Dovas A, Cox D, Condeelis J: Nck1 and Grb2 localization patterns can distinguish invadopodia from podosomes. Eur J Cell Biol 2010.
14. Li W, She H: The SH2 and SH3 adapter Nck: a two-gene family and a linker between tyrosine kinases and multiple signaling networks. Histol Histopathol 2000, 15:947-955.

15. Latreille M, Laberge MK, Bourret G, Yamani L, Larose L: Deletion of Nck1 attenuates hepatic ER stress signaling, improves glucose tolerance and insulin signaling in liver of obese mice. American journal of physiology 2011, E423-E434.

16. Chou MM, Fajardo JE, Hanafusa H: The SH2- and SH3-Containing Nck Protein Transforms Mammalian Fibroblasts in the Absence of Elevated Phosphotyrosine Levels. Mol Cell Biol 1992, 12(12):5834-5842.

17. Li W, Hu P, Skolnik EY, Ullrich A, Schlessinger J: The SH2 and SH3 DomainContaining Nck Protein Oncogenic and a Common Target for Phosphorylation by Different Surface Receptors. Mol Cell Biol 1992, 12(12):5824-5833.

18. de Wit NJ, Rijntjes J, Diepstra JH, van Kuppevelt TH, Weidle UH, Ruiter DJ, van Muijen GN: Analysis of differential gene expression in human melanocytic tumour lesions by custom made oligonucleotide arrays. British journal of cancer 2005, 92(12):2249-2261.

19. The Wistar melanoma Cell Lines. [http://www.wistar.org/lab/meenhardherlyn-dvm-dsc/page/melanoma-cell-lines-metastatic-melanoma-cell-linesthe-primary-le-0].

20. Smalley KS, Contractor R, Haass NK, Lee JT, Nathanson KL, Medina CA, Flaherty KT, Herlyn M: Ki67 expression levels are a better marker of reduced melanoma growth following MEK inhibitor treatment than phospho-ERK levels. British journal of cancer 2007, 96(3):445-449.

21. Lussier G, Larose L: A Casein Kinase I activity is constitutively associated with Nck. J Biol Chem 1997, 272:2688-2694.

22. Kelm JM, Timmins NE, Brown CJ, Fussenegger M, Nielsen LK: Method for generation of homogeneous multicellular tumor spheroids applicable to a wide variety of cell types. Biotechnol Bioeng 2003, 83(2):173-180.

23. Graeven U, Rodeck U, Karpinski S, Jost M, Philippou S, Schmiegel W: Modulation of Angiogenesis and Tumorigenicity of Human Melanocytic Cells by Vascular Endothelial Growth Factor and Basic Fibroblast Growth Factor. Cancer research 2001, 61(19):7282-7290.

24. Iliopoulos D, Ernst C, Steplewski Z, Jambrosic JA, Rodeck U, Herlyn M, Clark WH Jr, Koprowski H, Herlyn D: Inhibition of Metastases of a Human Melanoma Xenograft by Monoclonal Antibody to the GD2/GD3 Gangliosides. J Nat/ Cancer Inst 1989, 81(6):440-444.

25. Mayer BJ, Hamaguchi M, Hanafusa H: Characterization of p47gag-crk, a novel oncogene product with sequence similarity to a putative modulatory domain of protein-tyrosine kinases and phospholipase $C$. Cold Spring Harb Symp Quant Biol 1988, 53(Pt 2):907-914.

26. Watanabe T, Tsuda M, Tanaka S, Ohba Y, Kawaguchi H, Majima T, Sawa H, Minami A: Adaptor Protein Crk Induces Src-Dependent Activation of p38 MAPK in Regulation of Synovial Sarcoma Cell Proliferation. Molecular Cancer Research 2009, 7(9):1582-1592.

27. Crowley E, Horwitz AF: Tyrosine phosphorylation and cytoskeletal tension regulate the release of fibroblast adhesions. The Journal of cell biology 1995, 131(2):525-537.

28. Zamir E, Katz BZ, Aota S, Yamada KM, Geiger B, Kam Z: Molecular diversity of cell-matrix adhesions. Journal of cell science 1999, 112(Pt 11):1655-1669.

29. Chan KT, Cortesio CL, Huttenlocher A: FAK alters invadopodia and focal adhesion composition and dynamics to regulate breast cancer invasion. The Journal of cell biology 2009, 185(2):357-370.

30. Mader CC, Oser M, Magalhaes MAO, Bravo-Cordero JJ, Condeelis J, Koleske AJ, Gil-Henn H: An EGFR-Src-Arg-Cortactin Pathway Mediates Functional Maturation of Invadopodia and Breast Cancer Cell Invasion. Cancer research 2011, 71(5):1730-1741.

31. Smith-Pearson PS, Greuber EK, Yogalingam G, Pendergast AM: Abl Kinases Are Required for Invadopodia Formation and Chemokine-induced Invasion. Journal of Biological Chemistry 2010, 285(51):40201-40211.

32. Balzer EM, Whipple RA, Thompson K, Boggs AE, Slovic J, Cho EH, Matrone MA, Yoneda T, Mueller SC, Martin SS: c-Src differentially regulates the functions of microtentacles and invadopodia. Oncogene 2010, 29(48):6402-6408.

33. Kelley LC, Ammer AG, Hayes KE, Martin KH, Machida K, Jia L, Mayer BJ, Weed SA: Oncogenic Src requires a wild-type counterpart to regulate invadopodia maturation. Journal of cell science 2010,

123(22):3923-3932. 
34. Fantus IG, Kadota S, Deragon G, Foster B, Posner BI: Pervanadate [peroxide (s) of vanadate] mimics insulin action in rat adipocytes via activation of the insulin receptor tyrosine kinase. Biochemistry 1989, 28(22):8864-8871.

35. Kadota S, Fantus IG, Deragon G, Guyda HJ, Hersh B, Posner BI: Peroxide(s) of vanadium: a novel and potent insulin-mimetic agent which activates the insulin receptor kinase. Biochemical and biophysical research communications 1987, 147(1):259-266.

36. Posner Bl, Faure R, Burgess JW, Bevan AP, Lachance D, Zhang-Sun G, Fantus IG, Ng JB, Hall DA, Lum BS: Peroxovanadium compounds. A new class of potent phosphotyrosine phosphatase inhibitors which are insulin mimetics. Journal of Biological Chemistry 1994, 269(6):4596-4604.

37. Brattain MG, Strobel-Stevens J, Fine D, Webb M, Sarrif AM: Establishment of mouse colonic carcinoma cell lines with different metastatic properties. Cancer research 1980, 40(7):2142-2146.

38. Lacroix M, Leclercq G: Relevance of breast cancer cell lines as models for breast tumours: an update. Breast cancer research and treatment 2004, 83(3):249-289.

39. Neve RM, Chin K, Fridlyand J, Yeh J, Baehner FL, Fevr T, Clark L, Bayani N, Coppe JP, Tong F, et al: A collection of breast cancer cell lines for the study of functionally distinct cancer subtypes. Cancer cell 2006, 10(6):515-527

40. Takeichi M: Morphogenetic roles of classic cadherins. Curr Opin Cell Biol 1995, 7(5):619-627.

41. Perl AK, Wilgenbus $P$, Dahl U, Semb H, Christofori G: A causal role for Ecadherin in the transition from adenoma to carcinoma. Nature 1998, 392(6672):190-193.

42. Frixen UH, Behrens J, Sachs M, Eberle G, Voss B, Warda A, Lochner D, Birchmeier W: E-cadherin-mediated cell-cell adhesion prevents invasiveness of human carcinoma cells. The Journal of cell biology 1991, 113(1):173-185.

43. Mbalaviele G, Dunstan CR, Sasaki A, Williams PJ, Mundy GR, Yoneda T: Ecadherin expression in human breast cancer cells suppresses the development of osteolytic bone metastases in an experimental metastasis model. Cancer research 1996, 56(17):4063-4070.

44. Hynes RO: Integrins: versatility, modulation, and signaling in cell adhesion. Cell 1992, 69(1):11-25.

45. Giancotti FG, Mainiero F: Integrin-mediated adhesion and signaling in tumorigenesis. Biochim Biophys Acta 1994, 1198(1):47-64.

46. Juliano RL, Varner JA: Adhesion molecules in cancer: the role of integrins. Curr Opin Cell Biol 1993, 5(5):812-818.

47. Giancotti FG, Tarone G: Positional control of cell fate through joint integrin/receptor protein kinase signaling. Annu Rev Cell Dev Biol 2003, 19:173-206.

48. Goicoechea SM, Tu Y, Hua Y, Chen K, Shen TL, Guan JL, Wu C: Nck-2 interacts with focal adhesion kinase and modulates cell motility. The international journal of biochemistry \& cell biology 2002, 34(7):791-805.

49. Guo W, Giancotti FG: Integrin signalling during tumour progression. Nat Rev Mol Cell Biol 2004, 5(10):816-826.

50. Holland SJ, Gale NV, Gish GD, Roth RA, Songyang Z, Cantley LC, Henkemeyer M, Yancopoulos GD, Pawson T: Juxtamembrane tyrosine residues couple the Eph family receptor EphB2/Nuk to specific $\mathrm{SH}_{2}$ domain proteins in neuronal cells. EMBO J 1997, 16(13):3877-3888.

51. Lee C-H, Li W, Zhou M, Batzer AG, Myers MG, White MF, Schlessinger J, Skolnik EY: Nck associates with the SH2 domain-docking protein IRS-1 in insulin-stimulated cells. Proc Natl Acad Sci USA 1993, 90:11713-11717.

52. Meisenhelder J, Hunter T: The SH2/SH3 Domain-Containing Protein Nck Is Recognized by Certain Anti-Phospholipase C $-\gamma 1$ Monoclonal Antibodies, And Its Phosphorylation on Tyrosine Is Stimulated by Platelet-Derived Growth Factor and Epidermal Growth Factor Treatment. Mol Cell Biol 1992, 12(12):5843-5856.

53. Park D, Rhee SG: Phosphorylation of Nck in Response to a Variety of Receptors, Phorbol Myristate Acetate, and Cyclic AMP. Mol Cell Biol 1992, 12(12):5816-5823.

54. Stein E, Huynh-Do U, Lane AA, Ceretti DP, Daniel TO: Nck Recruitment to Eph Receptor, EphB1/ELK, Couples Ligand Activation to c-Jun Kinase. J Biol Chem 1998, 273(3):1303-1308

55. Tu Y, Li F, Wu C: Nck-2, a Novel Src Homology 2/3-containing Adaptor Protein That Interacts with the LIM-only Protein PINCH and Components of Growth Factor Receptor Kinase-signaling Pathways. Mol Biol Cell 1998, 9:3367-3382
56. Tu Y, Li F, Goicoechea S, Wu C: The LIM-only protein PINCH directly interacts with the integrin-linked kinase and is recruited to integrin-rich sites in spreading cells. M Cell Biol 1999, 19:2425-2434.

57. Wu C, Dedhar S: Integrin-linked kinase (ILK) and its interactors: a new paradigm for the coupling of extracellular matrix to actin cytoskeleton and signaling complexes. The Journal of cell biology 2001, 155(4):505-510.

58. Zhang Y, Guo L, Chen K, Wu C: A critical role of the PINCH-integrin-linked kinase interaction in the regulation of cell shape change and migration. The Journal of biological chemistry 2002, 277(1):318-326.

59. Blasutig IM, New LA, Thanabalasuriar A, Dayarathna TK, Goudreault M, Quaggin SE, Li SS, Gruenheid S, Jones N, Pawson T: Phosphorylated YDXV motifs and Nck SH2/SH3 adaptors act cooperatively to induce actin reorganization. Molecular and cellular biology 2008, 28(6):2035-2046.

60. Li X, Meriane M, Triki I, Shekarabi M, Kennedy TE, Larose L, LamarcheVane N: The adaptor protein Nck-1 couples the netrin-1 receptor DCC (deleted in colorectal cancer) to the activation of the small GTPase Rac1 through an atypical mechanism. The Journal of biological chemistry 2002, 277(40):37788-37797.

61. Antoku S, Saksela K, Rivera GM, Mayer BJ: A crucial role in cell spreading for the interaction of Abl PxxP motifs with Crk and Nck adaptors. Journal of cell science 2008, 121(Pt 18):3071-3082.

62. Smith JM, Katz S, Mayer BJ: Activation of the Abl tyrosine kinase in vivo by Src homology 3 domains from the Src homology2/Src homology 3 adaptor Nck. J Biol Chem 1999, 274(39):27956-27962.

63. Preisinger $C$, Kolch $\mathrm{W}$ : The Bcr-Abl kinase regulates the actin cytoskeleton via a GADS/SIp-76/Nck1 adaptor protein pathway. Cellular signalling 2010, 22(5):848-856.

64. Lee JH, Pyon J-K, Kim DW, Lee SH, Nam HS, Kim CH, Kang SG, Lee YJ, Park MY, Jeong DJ, et al: Elevated c-Src and c-Yes expression in malignant skin cancers. Journal of Experimental \& Clinical Cancer Research 2010, 29(1):116.

65. Stylli SS, Stacey TT, Verhagen AM, Xu SS, Pass I, Courtneidge SA, Lock P: Nck adaptor proteins link Tks5 to invadopodia actin regulation and ECM degradation. Journal of cell science 2009, 122(Pt 15):2727-2740.

66. Yamaguchi H, Lorenz M, Kempiak S, Sarmiento C, Coniglio S, Symons M, Segall J, Eddy R, Miki H, Takenawa T, et al: Molecular mechanisms of invadopodium formation: the role of the N-WASP-Arp $2 / 3$ complex pathway and cofilin. The Journal of cell biology 2005, 168(3):441-452.

67. Ayala I, Baldassarre M, Giacchetti G, Caldieri G, Tete S, Luini A, Buccione R: Multiple regulatory inputs converge on cortactin to control invadopodia biogenesis and extracellular matrix degradation. Journal of cell science 2008, 121(Pt 3):369-378.

68. Chen WT: Proteolytic activity of specialized surface protrusions formed at rosette contact sites of transformed cells. J Exp Zool 1989, 251(2):167-185.

69. Condeelis J, Segall JE: Intravital imaging of cell movement in tumours. Nature reviews 2003, 3(12):921-930.

70. Buccione R, Orth JD, McNiven MA: Foot and mouth: podosomes, invadopodia and circular dorsal ruffles. Nat Rev Mol Cell Biol 2004, 5(8):647-657.

71. McNiven MA, Baldassarre M, Buccione R: The role of dynamin in the assembly and function of podosomes and invadopodia. Front Biosci 2004, 9:1944-1953.

\section{Pre-publication history}

The pre-publication history for this paper can be accessed here: http://www.biomedcentral.com/1471-2407/11/443/prepub

\section{doi:10.1186/1471-2407-11-443}

Cite this article as: Labelle-Côté et al:: Nck2 promotes human melanoma cell proliferation, migration and invasion in vitro and primary melanoma-derived tumor growth in vivo. BMC Cancer 2011 $11: 443$ 